\title{
A Middle-Aged Enzyme Still in Its Prime: Recent Advances in the Field of Cutinases
}

\author{
Efstratios Nikolaivits ${ }^{1,+}+\mathbb{D}$, Maria Kanelli ${ }^{1,+}{ }^{+}$, Maria Dimarogona ${ }^{2} \mathbb{D}$ and Evangelos Topakas ${ }^{1, *(D)}$ \\ 1 IndBioCat Group, Biotechnology Laboratory, School of Chemical Engineering, National Technical University \\ of Athens, 9 Heroon Polytechniou Str., Zographou Campus, 15780 Athens, Greece; \\ snikolai@central.ntua.gr (E.N.); mkanelli@chemeng.ntua.gr (M.K.) \\ 2 Department of Chemical Engineering, University of Patras, 26504 Patras, Greece; \\ mdimarog@chemeng.upatras.gr \\ * Correspondence: vtopakas@chemeng.ntua.gr; Tel.: +30-210-772-3264 \\ + These authors have contributed equally in this work.
}

Received: 7 November 2018; Accepted: 27 November 2018; Published: 3 December 2018

\begin{abstract}
Cutinases are $\alpha / \beta$ hydrolases, and their role in nature is the degradation of cutin. Such enzymes are usually produced by phytopathogenic microorganisms in order to penetrate their hosts. The first focused studies on cutinases started around 50 years ago. Since then, numerous cutinases have been isolated and characterized, aiming at the elucidation of their structure-function relations. Our deeper understanding of cutinases determines the applications by which they could be utilized; from food processing and detergents, to ester synthesis and polymerizations. However, cutinases are mainly efficient in the degradation of polyesters, a natural function. Therefore, these enzymes have been successfully applied for the biodegradation of plastics, as well as for the delicate superficial hydrolysis of polymeric materials prior to their functionalization. Even though research on this family of enzymes essentially began five decades ago, they are still involved in many reports; novel enzymes are being discovered, and new fields of applications arise, leading to numerous related publications per year. Perhaps the future of cutinases lies in their evolved descendants, such as polyesterases, and particularly PETases. The present article reviews the biochemical and structural characteristics of cutinases and cutinase-like hydrolases, and their applications in the field of bioremediation and biocatalysis.
\end{abstract}

Keywords: cutinase; crystal structure; polyester hydrolysis; plastics degradation; depolymerization; surface functionalization; polymerization; ester synthesis; biocatalysis

\section{Introduction}

Cutin is the part of the cuticular membrane that covers the aerial parts (e.g., leaves and fruits) of higher plants. It is a biopolymer that consists mostly of esterified $C_{16}$ and $C_{18}$ oxygenated fatty acids [1] and it is considered as the first barrier that is encountered by plant pathogens on their way to penetration (Figure 1). In order to overcome this obstacle, plant pathogens use various tools such as cutinase enzymes [2-4], which in some cases, are necessary for pathogenicity [5-8].

The first recorded reports of cutinase activity are traced back to the early 1960s [9], while in 1970, Sishiyama et al. characterized a crude cutin-esterase enzymatic preparation from Botrytis cinerea for hydrolyzing tomato cutin [10]. More focused studies were performed by Kolattukudy and his coworkers, who had first investigated the synthesis and lipid composition of cutin in plants [11]; they subsequently focused on the depolymerization of the latter by extracellular enzyme preparations from Fusarium solani pisi, and further isolated and characterized its cutinases [12,13]. 


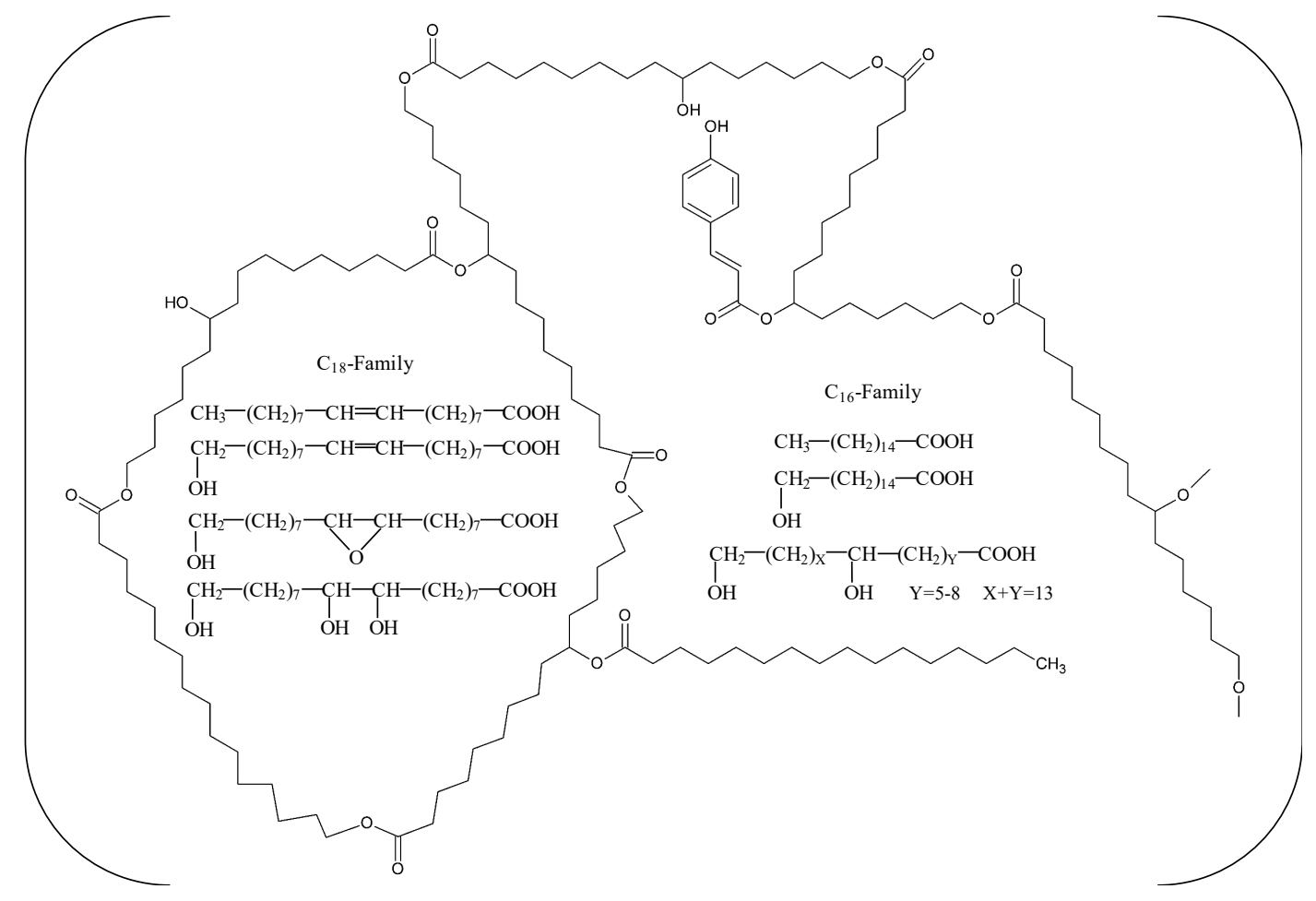

Figure 1. The possible molecular structure of cutin.

F. solani cutinase $\left(\mathrm{FsC}_{\mathrm{S}}\right)$ was the first to be studied in detail, especially after its cloning and expression in heterologous hosts, which also led to the determination of its crystal structure. Studies regarding its biocatalytic potential for hydrolytic and synthetic reactions are summarized in an early review by Carvalho et al. [14]. The discovery of new fungal and bacterial cutinases led to the expansion of their applications in different areas of interest, such as detergents, ester synthesis, and food processing; however, in most cases, cutinases were considered as an alternative to lipases [15]. Nevertheless, these enzymes found their true calling in the textile industry for the modification of fabrics, as thoroughly described by Chen et al. in their review article in 2013 [16]. According to Scopus (www.scopus.com), "cutinase" has been mentioned in 254 publications since 2013 (165 since 2015); therefore, this review focuses on the findings of the last five years regarding this family of enzymes. This review paper provides the most recent knowledge regarding cutinases or cutinase-like hydrolases. More specifically, it focuses on combining information both on the enzymes' biochemical and structural characteristics, and their applications in the field of biocatalysis in terms of material hydrolytic degradation as well as synthesis, whereas strategies for improving enzyme activity and stability are described.

\section{Biochemical Characteristics}

Cutinases (E.C. 3.1.1.74) are serine esterases that belong to the $\alpha / \beta$ hydrolase family. Since the isolation and study of $\mathrm{FsC}$, numerous new fungal and bacterial cutinases have been discovered and characterized (Table 1). Most fungal cutinase genes have been heterologously expressed in Pichia pastoris or in other eukaryotic hosts, such as Saccharomyces cerevisiae [17], Trichoderma reesei [18] and Arxula adeninivorans [19]). Only Fusarium-derived cutinases have been expressed in Escherichia coli strains (WK-6 [20], BL21 [21] and Origami 2 [22]). On the contrary, bacterial cutinases have been expressed, as expected, only in E. coli strains, mostly BL21, with very few exceptions [23,24]. Furthermore, only a limited number of cutinases have been isolated and characterized from wild-type (WT) microorganisms, such as Thielavia terrestris [25,26], Cryptococcus magnus [27], Paraphoma sp. [28], Aspergillus oryzae [29], and Aspergillus nidulans [30]. 
The molecular weight (MW) of fungal cutinases ranges from 20 to $25 \mathrm{kDa}$, with very few exceptions, such as THCUT1 from Trichoderma harzianum [31], Acut3-6hp from Arxula adeninivorans [19], ANCUT2 from A. nidulans [30], and TtcutB from T. terrestris [25], with MWs varying between 27.3 and $29.2 \mathrm{kDa}$. On the other hand, the MW of bacterial cutinases is usually around $30 \mathrm{kDa}$, with only two characterized enzymes from Thermomonospora curvata exhibiting a higher size of $35 \mathrm{kDa}$ [24].

As a rule, cutinases work optimally at neutral or alkaline $\mathrm{pH}(7.0-9.5)$. However, there are some reports of cutinases that prefer slightly acidic ( $\mathrm{pH} 6)[18,32,33]$ or acidic $(\mathrm{pH} 4-5)[19,25,26,34]$ conditions. Regarding the effect of temperature, bacterial cutinases act optimally at $50-60{ }^{\circ} \mathrm{C}$, probably due to the fact that they all derive from thermophilic sources. On the contrary, most characterized fungal cutinases exhibit temperature optima of $40-45{ }^{\circ} \mathrm{C}$ and some even lower, in the vicinity of $20-30{ }^{\circ} \mathrm{C}$. There are three reported cutinases with optimum activity temperatures at $50{ }^{\circ} \mathrm{C}$, and two at higher temperatures $\left(55-60^{\circ} \mathrm{C}\right)$, as seen in Table 1 .

Cutinases have a broad substrate range, hydrolyzing soluble fatty acid esters, triglycerides, and insoluble polymers; hence, they have been categorized between esterases and true lipases, tending to have higher affinities for short-chain esters. Based on substrate specificity studies with $p$-nitrophenyl $(p N P)$ esters, it can be deduced that the majority of cutinases prefer chain lengths of two to four carbon atoms or a little longer $\left(\mathrm{C}_{5}-\mathrm{C}_{6}\right)$ (Table 1). Humicola insolens, Glomerella cingulata, and Cryptococcus magnus cutinases show differentiated catalytic profiles favoring the hydrolysis of $C_{8}$ and $C_{12}$ esters.

\section{Structural Characteristics}

Cutinases belong to the superfamily of serine $\alpha / \beta$-hydrolases. They have a Ser-His-Asp catalytic triad, and two additional residues that form an oxyanion hole via their main-chain amides, stabilizing the transition states. The cutinase mechanism of hydrolysis is accomplished in two acylation/deacylation steps, including the formation of a covalent intermediate between the carbonyl group of the ester being hydrolyzed, and the catalytic serine. Currently, there are eight fungal and six bacterial cutinases whose structures have been determined by $\mathrm{X}$-ray crystallography (Table 2). The first determined cutinase structure was from F. solani pisi (FsC) (Figure 2A) [35]. This was followed by an extensive structural characterization of FsC mutants and inhibitor complexes, which shed light on the dynamics and mechanism of action of cutinase enzymes [36].
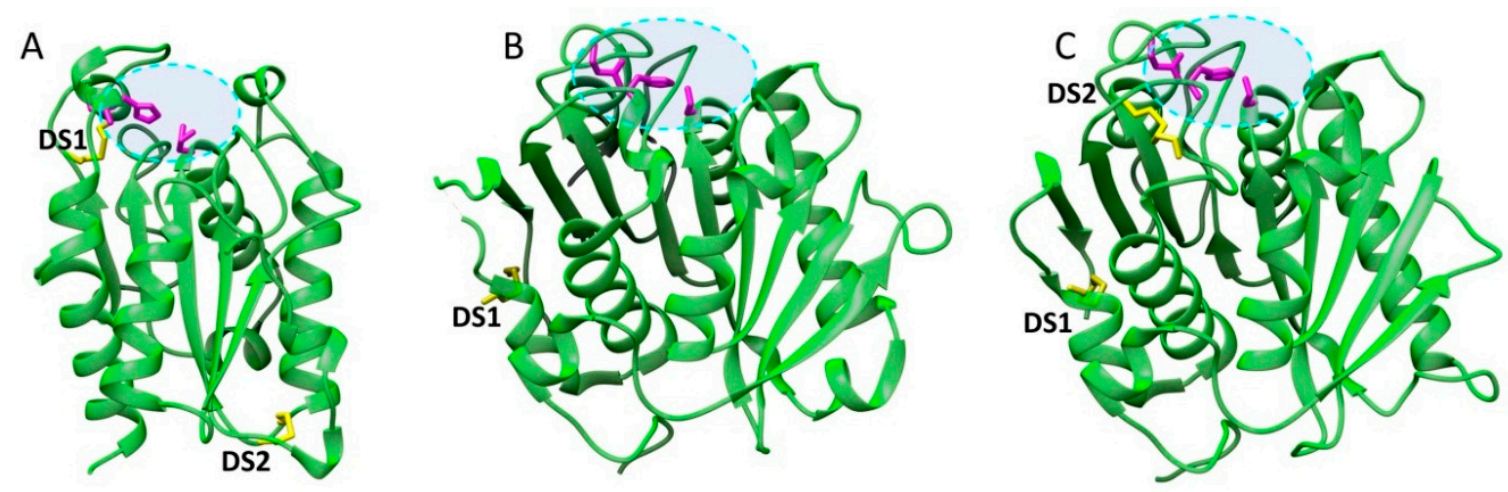

Figure 2. Overall structures of (A) Fsp cutinase (PDB code 1CEX) [37], (B) Thermobifida fusca cutinase (PDB code 4CG1) [38], and (C) Ideonella sakaiensis PETase (PDB code 15XG0) [39]. Catalytic triad residues, colored magenta, and disulphide bonds (DS), colored yellow, are shown in sticks. Turquoise dashed circles mark the substrate binding cleft. 
Table 1. Biochemical characteristics of known cutinases isolated from their WT (wild-type) organism or expressed in a heterologous host. Molecular weight (MW), optimum temperature and $\mathrm{pH}$, isoelectric point, specific activity, and/or kinetic constants on $p$-nitrophenyl butyrate, substrate specificity on different $p$-nitrophenyl esters, and thermostability expressed as residual activity after incubation or as a half-life at a specific temperature.

\begin{tabular}{|c|c|c|c|c|c|c|c|c|c|c|c|}
\hline Name & Origin & $\begin{array}{c}\text { Gene Accession } \\
\text { Number }\end{array}$ & Host & MW (kDa) & $\mathrm{T}_{\mathrm{opt}}\left({ }^{\circ} \mathrm{C}\right)$ & $\mathrm{pH}_{\mathrm{opt}}$ & $\mathrm{pI}$ & $\begin{array}{c}\text { Kinetics/Activity on } \\
p \mathrm{NPB}\end{array}$ & $\begin{array}{c}p \text { NP-Ester } \\
\text { Specificity }\left(k_{\text {cat }} / K_{M}\right)\end{array}$ & $\begin{array}{l}\text { Thermostability } \\
\text { Half-Life }\left(t_{1 / 2}\right)\end{array}$ & Ref. \\
\hline \multicolumn{12}{|c|}{ Bacterial Sources } \\
\hline Tfu_0883 & Thermobifida fusca & YP_288943 & $\begin{array}{l}\text { E. coli BL21 Rosetta } \\
\text { (DE3) PlysS cells }\end{array}$ & 29 & 60 & 8 & & $458 \mathrm{U} / \mathrm{mg}$ & & $\mathrm{t}_{1 / 2}\left(60^{\circ} \mathrm{C}\right)=40 \mathrm{~h}$ & [40] \\
\hline Tfu_0882 & Thermobifida fusca & YP_288944 & $\begin{array}{l}\text { E. coli BL21 Rosetta } \\
\text { (DE3) PlysS cells }\end{array}$ & 29 & 60 & 8 & & $223 \mathrm{U} / \mathrm{mg}$ & & & [40] \\
\hline Thc_Cut1 & $\begin{array}{l}\text { Thermobifida } \\
\text { cellulosilytica }\end{array}$ & HQ147785 & E.coli BL21-Gold (DE3) & 29.4 & & & & $\begin{array}{l}1.48 \mathrm{mM} \\
195.1 \mathrm{~s}^{-1}\end{array}$ & $\mathrm{C}_{2}$ & & [41] \\
\hline Thc_Cut2 & $\begin{array}{l}\text { Thermobifida } \\
\text { cellulosilytica }\end{array}$ & HQ147786 & E.coli BL21-Gold (DE3) & 29.7 & & & & $\begin{array}{c}2.13 \mathrm{mM} \\
5.3 \mathrm{~s}^{-1}\end{array}$ & $\mathrm{C}_{2}$ & & [41] \\
\hline Thf42_cut1 & Thermobifida fusca & HQ147787 & E.coli BL21-Gold (DE3) & 29.6 & & & & $\begin{array}{l}2.10 \mathrm{mM} \\
30.9 \mathrm{~s}^{-1}\end{array}$ & $\mathrm{C}_{2}$ & & [41] \\
\hline Tha_Cut1 & Thermobifida alba & HQ147784 & E.coli BL21-Gold (DE3) & 28.1 & & & & $\begin{array}{l}1.93 \mathrm{mM} \\
6.03 \mathrm{~s}^{-1} \\
\end{array}$ & $\mathrm{C}_{2}$ & & [42] \\
\hline Est119 & $\begin{array}{l}\text { Thermobifida alba } \\
\text { AHK119 }\end{array}$ & est119 & $\begin{array}{l}\begin{array}{l}\text { E. coli Rosetta-gami B } \\
\text { (DE3) }\end{array}\end{array}$ & 30 & 50 & 6 & & $\begin{array}{c}2.3 \mathrm{U} / \mathrm{mg} \\
3.41 \mathrm{mM} \\
4.48 \mathrm{~s}^{-1} \\
1.31 \mathrm{~s}^{-1} \mathrm{mM}^{-1} \\
\end{array}$ & $\mathrm{C}_{6}$ & & [23] \\
\hline Cut1 & Thermobifida fusca & JN129499.1 & E. coli BL21 (DE3) & 30.1 & 55 & 8 & & $\begin{array}{c}542.5 \mathrm{U} / \mathrm{mg} \\
0.13 \mathrm{mM} \\
178 \mathrm{~s}^{-1} \\
13.69 \mathrm{~s}^{-1} \mathrm{mM}^{-1} \\
\end{array}$ & $\mathrm{C}_{4}{ }^{*}$ & Stable at $37^{\circ} \mathrm{C}$ & [43] \\
\hline Cut2 & Thermobifida fusca & JN129500.1 & E. coli BL21 (DE3) & 29.6 & 55 & 8 & & $\begin{array}{c}643.4 \mathrm{U} / \mathrm{mg} \\
0.09 \mathrm{mM} \\
253 \mathrm{~s}^{-1} \\
2840 \mathrm{~s}^{-1} \mathrm{mM}^{-1}\end{array}$ & $\mathrm{C}_{4} *$ & $\begin{array}{c}\text { Stable at } 37^{\circ} \mathrm{C} \\
\mathrm{t}_{1 / 2}\left(55^{\circ} \mathrm{C}\right)=30 \mathrm{~h}\end{array}$ & [43] \\
\hline Tcur1278 & $\begin{array}{l}\text { Thermomonospora } \\
\text { curvata }\end{array}$ & HG939554 & E. coli TOP10 & 35 & 60 & 8.5 & & $3 \mathrm{U} / \mathrm{mg}$ & & $\begin{array}{l}80 \% \text { act at } 50^{\circ} \mathrm{C} \text { and } \\
55^{\circ} \mathrm{C} \text { for } 60 \mathrm{~min}\end{array}$ & [24] \\
\hline Tcur0390 & $\begin{array}{c}\text { Thermomonospora } \\
\text { curvata }\end{array}$ & HG939555 & E. coli TOP10 & 35 & 55 & 8.5 & & $17.9 \mathrm{U} / \mathrm{mg}$ & & $\begin{array}{l}40 \% \text { act at } 50^{\circ} \mathrm{C} \text { for } \\
\quad 60 \mathrm{~min} \\
15 \% \text { action at } 55^{\circ} \mathrm{C} \\
\text { and } 60^{\circ} \mathrm{C} \text { for } 10 \mathrm{~min}\end{array}$ & [24] \\
\hline LC-cutinase & $\begin{array}{l}\text { Leaf-branch } \\
\text { compost } \\
\text { metagenome }\end{array}$ & HQ704839 & $\begin{array}{l}\text { E. coli } \\
\text { BL21-CodonPlus(DE3)-RP }\end{array}$ & 29 & 50 & 8.5 & 9.3 & & $\mathrm{C}_{4} *$ & $\begin{array}{l}\mathrm{t}_{1 / 2}\left(60^{\circ} \mathrm{C}\right)=80 \mathrm{~min} \\
\mathrm{t}_{1 / 2}\left(70^{\circ} \mathrm{C}\right)=40 \mathrm{~min}\end{array}$ & [44] \\
\hline
\end{tabular}


Table 1. Cont.

\begin{tabular}{|c|c|c|c|c|c|c|c|c|c|c|c|}
\hline Name & Origin & $\begin{array}{c}\text { Gene Accession } \\
\text { Number }\end{array}$ & Host & MW (kDa) & $\mathrm{T}_{\mathrm{opt}}\left({ }^{\circ} \mathrm{C}\right)$ & $\mathrm{pH}_{\mathrm{opt}}$ & pI & $\begin{array}{c}\text { Kinetics/Activity on } \\
p \mathrm{NPB}\end{array}$ & $\begin{array}{c}p \text { NP-Ester } \\
\text { Specificity }\left(k_{\text {cat }} / K_{M}\right)\end{array}$ & $\begin{array}{l}\text { Thermostability } \\
\text { Half-Life }\left(t_{1 / 2}\right)\end{array}$ & Ref. \\
\hline \multicolumn{12}{|c|}{ Fungal Sources } \\
\hline $\begin{array}{l}\text { F. solani } \\
\text { cutinase }\end{array}$ & Fusarium solani & К02640 & Pichia pastoris $\mathrm{X}-33$ & 20 & 40 & 8 & & & & & [45] \\
\hline MFCUT1 & Monilinia fructicola & AF305598 & Pichia pastoris & 22 & & & 8.4 & $\begin{array}{c}40.8 \mathrm{~min}^{-1} \\
1.23 \mu \mathrm{M} \\
5.5 \cdot 10^{-4} \mathrm{~s}^{-1} \mathrm{mM}^{-1}\end{array}$ & & & [31] \\
\hline CutL1 & Aspergillus oryzae & P52956 & WT & 21.6 & 50 & 9 & & $\begin{array}{c}0.22 \mathrm{mM} \\
18 \mathrm{~s}^{-1} \\
81.82 \mathrm{~s}^{-1} \mathrm{mM}^{-1}\end{array}$ & $\mathrm{C}_{5}$ & $\begin{array}{c}\text { Stable at } 40^{\circ} \mathrm{C} \text { for } 30 \\
\min \end{array}$ & [29] \\
\hline \multirow[t]{2}{*}{ THCUT1 } & $\begin{array}{l}\text { Trichoderma } \\
\text { harzianum }\end{array}$ & AJ896891 & Pichia pastoris GS115 & 29 & & $7.5-8$ & 4.2 & $\begin{array}{c}0.74 \mathrm{U} / \mathrm{mg} \\
0.57 \mathrm{mM}\end{array}$ & $\mathrm{C}_{2}$ & & [46] \\
\hline & Aspergillus oryzae & & Pichia pastoris & & & & & $\begin{array}{c}0.21 \mu \mathrm{M} \\
5.8 \cdot 10^{-5} \mathrm{~s}^{-1} \mathrm{mM}^{-1}\end{array}$ & $\mathrm{C}_{4}$ & & [47] \\
\hline CUTAB1 & Alternaria brassicicola & U03393.1 & Pichia pastoris X-33 & 24 & 40 & $7-9$ & $5.2-7$ & $1057 \mathrm{U} / \mathrm{mg}$ & $\mathrm{C}_{4}{ }^{*}$ & Stable at $40^{\circ} \mathrm{C}$ & [48] \\
\hline $\mathrm{HiC}$ & Humicola insolens & hic & Pichia pastoris X-33 & & 50 & & & $\begin{array}{c}0.45 \mathrm{mM} \\
191 \mathrm{~s}^{-1} \\
424.4 \mathrm{~s}^{-1} \mathrm{mM}^{-1}\end{array}$ & $\mathrm{C}_{8}$ & $\begin{array}{c}\text { Stable at } 50^{\circ} \mathrm{C} \text { for } \\
48 \mathrm{~h} \\
\mathrm{t}_{1 / 2}\left(85^{\circ} \mathrm{C}\right)=1 \mathrm{~h}\end{array}$ & [49] \\
\hline TtcutA & Thielavia terrestris & & WT & 25.3 & 50 & 4 & & $\begin{array}{c}1200 \mathrm{U} / \mathrm{mg} \\
1 \mathrm{mM} \\
0.62 \mathrm{~s}^{-1} \\
0.62 \mathrm{~s}^{-1} \mathrm{mM}^{-1}\end{array}$ & $\mathrm{C}_{4}$ & $\begin{array}{c}\text { Stable at } 65^{\circ} \mathrm{C} \text { for } 30 \\
\min \end{array}$ & [26] \\
\hline AnCut5 & Aspergillus niger & anig5 & Pichia pastoris $\mathrm{X}-33$ & 22.8 & & 6 & & & & & [33] \\
\hline CmCut1 & Cryptococcus magnus & & WT & 21 & 40 & 7.5 & & & $\mathrm{C}_{12}$ * & & [27] \\
\hline $\mathrm{PaE}$ & $\begin{array}{c}\text { Pseudozyma } \\
\text { antarctica }\end{array}$ & DM067526 & $\begin{array}{c}\text { Saccharomyces } \\
\text { cerevisiae }\end{array}$ & 20.4 & 40 & 9.5 & & $\sim 220 \mathrm{U} / \mathrm{mg}$ & & $\mathrm{t}_{1 / 2}\left(40^{\circ} \mathrm{C}\right)=\sim 1 \mathrm{~h}$ & [17] \\
\hline $\begin{array}{l}\text { G. cingulata } \\
\text { cutinase }\end{array}$ & Glomerella cingulata & AF444194 & Pichia pastoris X-33 & 25 & 25 & 8 & & & $\mathrm{C}_{8}$ & & [50] \\
\hline Tr cutinase & Trichoderma reesei & tre60489 v2.0 & Trichoderma reesei & 23.8 & & 6 & & $57 \mathrm{U} / \mathrm{mg}$ & & $\begin{array}{l}80 \% \text { act after } 20 \mathrm{~h} \text { at } \\
50^{\circ} \mathrm{C} \text { or } 1 \mathrm{~h} \text { at } 60^{\circ} \mathrm{C}\end{array}$ & [18] \\
\hline ScCut1 & Sirococcus conigenus & KF193402 & Pichia pastoris X-33 & 20 & & $4.7-5.2$ & & $1.7 \mathrm{mM}$ & $\mathrm{C}_{2}{ }^{*}$ & $\begin{array}{c}\mathrm{t}_{1 / 2}\left(55^{\circ} \mathrm{C}\right)=9.5 \mathrm{~h} \\
\mathrm{t}_{1 / 2}\left(85^{\circ} \mathrm{C}\right)=25 \mathrm{~min}\end{array}$ & [34] \\
\hline PCLE & $\begin{array}{l}\text { Paraphoma-related } \\
\text { strain }\end{array}$ & AB823702 & WT & 19.7 & 45 & 7.2 & & $\sim 13 \mathrm{U} / \mathrm{mg}$ & $\mathrm{C}_{5} *$ & & [28] \\
\hline
\end{tabular}


Table 1. Cont.

\begin{tabular}{|c|c|c|c|c|c|c|c|c|c|c|c|}
\hline Name & Origin & $\begin{array}{c}\text { Gene Accession } \\
\text { Number }\end{array}$ & Host & MW (kDa) & $\mathrm{T}_{\text {opt }}\left({ }^{\circ} \mathrm{C}\right)$ & $\mathrm{pH}_{\text {opt }}$ & $\mathrm{pI}$ & $\begin{array}{c}\text { Kinetics/Activity on } \\
p \text { NPB }\end{array}$ & $\begin{array}{c}p N P-E s t e r \\
\text { Specificity }\left(k_{\text {cat }} / K_{M}\right)\end{array}$ & $\begin{array}{l}\text { Thermostability } \\
\text { Half-Life }\left(t_{1 / 2}\right)\end{array}$ & Ref. \\
\hline TtcutB & Thielavia terrestris & & WT & 27.3 & 55 & 4 & & $\begin{array}{c}983 \mathrm{U} / \mathrm{mg} \\
1.1 \mathrm{mM} \\
0.85 \mathrm{~s}^{-1} \\
0.77 \mathrm{~s}^{-1} \mathrm{mM}^{-1}\end{array}$ & $\mathrm{C}_{4}$ & $\begin{array}{l}\mathrm{t}_{1 / 2}\left(70^{\circ} \mathrm{C}\right)=51 \mathrm{~min} \\
\mathrm{t}_{1 / 2}\left(80^{\circ} \mathrm{C}\right)=49 \mathrm{~min}\end{array}$ & [25] \\
\hline FoCut5a & Fusarium oxysporum & foqg__13916.1 & E. coli BL21 (DE3) & 23 & 40 & 8 & 7.9 & $\begin{array}{c}0.7 \mathrm{mM} \\
111.9 \mathrm{~s}^{-1} \\
152.5 \mathrm{~s}^{-1} \mathrm{mM}^{-1}\end{array}$ & $\mathrm{C}_{4}$ & $\begin{array}{l}\text { Deactivation after } \\
2 \mathrm{~h} \text { at } 35^{\circ} \mathrm{C}\end{array}$ & [21] \\
\hline Acut1-6hp & Arxula adeninivorans & LN828946 & A. adeninivorans G1212 & 21.6 & 20 & 5 & & $\begin{array}{c}66.1 \mathrm{U} / \mathrm{mg} \\
1.6 \mathrm{mM}\end{array}$ & $\mathrm{C}_{6}{ }^{*}$ & $\begin{array}{c}\text { Stable at } 25^{\circ} \mathrm{C} \text { for } \\
2 \mathrm{~h}\end{array}$ & [19] \\
\hline Acut2-6hp & Arxula adeninivorans & LN828947 & A. adeninivorans G1212 & 21.6 & 30 & 5 & & $\begin{array}{c}1747 \mathrm{U} / \mathrm{mg} \\
1.5 \mathrm{mM}\end{array}$ & $\mathrm{C}_{6}{ }^{*}$ & $\begin{array}{c}\text { Stable at } 40^{\circ} \mathrm{C} \text { for } \\
2 \mathrm{~h}\end{array}$ & [19] \\
\hline Acut3-6hp & Arxula adeninivorans & LN828948 & A. adeninivorans G1212 & 29.2 & 30 & 5.5 & & $\begin{array}{c}1251 \mathrm{U} / \mathrm{mg} \\
1.9 \mathrm{mM}\end{array}$ & $\mathrm{C}_{4} *$ & $\begin{array}{c}\text { Stable at } 50^{\circ} \mathrm{C} \text { for } \\
4 \mathrm{~h}\end{array}$ & [19] \\
\hline ANCUT2 & Aspergillus nidulans & $\begin{array}{l}\text { ABF50887 } \\
\text { (protein) }\end{array}$ & WT & 29 & 60 & 9 & 5.05 & $\sim 350 \mathrm{U} / \mathrm{mg}$ & $\mathrm{C}_{2}$ * & $\begin{array}{c}60 \% \text { act after } 1 \mathrm{~h} \text { at } \\
60{ }^{\circ} \mathrm{C} \\
\end{array}$ & [30] \\
\hline McCut & $\begin{array}{l}\text { Malbranchea } \\
\text { cinnamomea }\end{array}$ & KY568910.1 & Pichia pastoris GS115 & 21.9 & 45 & 8 & & $\begin{array}{c}1147.9 \mathrm{U} / \mathrm{mg} \\
0.66 \mathrm{mM} \\
0.46 \mathrm{~s}^{-1} \\
0.70 \mathrm{~s}^{-1} \mathrm{mM}^{-1}\end{array}$ & $\mathrm{C}_{6}$ & $\begin{array}{l}\mathrm{t}_{1 / 2}\left(80^{\circ} \mathrm{C}\right)=92 \mathrm{~min} \\
\mathrm{t}_{1 / 2}\left(85^{\circ} \mathrm{C}\right)=67 \mathrm{~min}\end{array}$ & [51] \\
\hline MtCUT & $\begin{array}{l}\text { Myceliophthora } \\
\text { thermophila }\end{array}$ & XP_003663956.1 & Pichia pastoris $\mathrm{KM} 71 \mathrm{H}$ & 23.4 & 30 & 8.5 & & $2.34 \mathrm{mM}$ & $\mathrm{C}_{4}$ & $\begin{array}{c}\text { Stable at } 25^{\circ} \mathrm{C} \text { for } 20 \\
\min \end{array}$ & [52] \\
\hline
\end{tabular}

${ }^{*}$ Based on specific activity $(\mathrm{U} / \mathrm{mg})$ measurements and not $k_{\text {cat }} / K_{M}$. 
Contrary to true lipases, most cutinases do not have a lid covering their active site, resulting in the nucleophilic serine being exposed to the solvent. An exception is a cutinase-like enzyme from T. reesei, which has a lid that covers the active site residues, and which is formed by two $N$-terminal helices. The location of the lid differs from the one observed in lipases [18]. FsC active site has been shown to display relative flexibility, which is related to its ability to harbor a variety of substrates [37]. Both fungal and bacterial cutinases share a similar overall $\alpha / \beta$ fold; however, bacterial ones are in general larger than their fungal counterparts. Most differences among bacterial and fungal cutinases are observed in the $\mathrm{N}$ - and C-terminal regions [38]. In addition, while most bacterial cutinases have one disulphide (DS) bond, fungal cutinases feature 2-3 DS bonds (Figure 2A,B).

Table 2. Available crystal structures of fungal and bacterial cutinases.

\begin{tabular}{|c|c|c|c|c|}
\hline & No & PDB ID & Microorganism & Reference \\
\hline \multirow{8}{*}{$\begin{array}{c}\text { Fungal } \\
\text { cutinases }\end{array}$} & 1 & 1CUS & Fusarium solani pisi & [35] \\
\hline & 2 & $2 \mathrm{CZQ}$ & Cryptococcus sp. & [53] \\
\hline & 3 & $3 \mathrm{DCN}$ & Glomerella cingulata & [54] \\
\hline & 4 & 3GBS & Aspergillus oryzae & [47] \\
\hline & 5 & $4 O Y Y$ & Humicola insolens & [55] \\
\hline & 6 & 4PSC & Trichoderma reesei & [18] \\
\hline & 7 & $5 \mathrm{AJH}$ & Fusarium oxysporum & [21] \\
\hline & 8 & $5 \times 88$ & Malbranchea cinnamomea & [51] \\
\hline \multirow{7}{*}{$\begin{array}{l}\text { Bacterial } \\
\text { cutinases }\end{array}$} & 1 & 3VIS & Thermobifida alba & [56] \\
\hline & 2 & $4 \mathrm{EBO}$ & Leaf branch compost bacterial cutinase & [57] \\
\hline & 3 & 4CG1 & Thermobifida fusca & [38] \\
\hline & 4 & 4WFI & Saccharomonospora viridis & [58] \\
\hline & 5 & $5 \mathrm{LUI}$ & Thermobifida cellulosilytica (Thc_Cut1) & [59] \\
\hline & 6 & $5 \mathrm{LUJ}$ & T. cellulosilytica (Thc_Cut2) & [59] \\
\hline & 7 & $5 X G 0$ & Ideonella sakaiensis & [39] \\
\hline
\end{tabular}

\subsection{Structural Determinants of Cutinase Stability}

Due to the industrial relevance of cutinases, a lot of effort has been attributed to the identification of the structural elements that influence the stability of these enzymes against temperature, $\mathrm{pH}$, and organic solvents, with the aim to engineer more robust biocatalysts. The degradation of rigid polymers has to be performed at or over their glass transition temperature $\left(T_{\mathrm{g}}\right)$, which in the case of poly(ethylene terephthalate) (PET) is $70{ }^{\circ} \mathrm{C}$. It is thus obvious that thermostable cutinases are required for industrial applications. A comparative analysis of two highly homologous T. fusca cutinases that differ in terms of structural stability, showed that the latter is determined by various parameters, such as the occurrence of solvent-accessible hydrophobic residues, the surface charge distribution, and the compactness of the protein [60]. Cutinases with increased thermostability have been successfully engineered through the introduction of proline residues in loop regions [23] that carry the catalytic amino acids. The increased thermostability of cutinase from Malbranchea cinnamomea has been attributed to the natural occurrence of an increased number of proline residues in the loop regions of its structure [51]. In the case of A. oryzae cutinase (AoC), its thermostability was improved by using a rational design approach. The introduction of proline residues and surface salt bridges as well as the modification of surface charges resulted in mutants with increased melting temperature $\left(T_{\mathrm{m}}\right)$. However, most variants lost their activity at temperatures well below the thermal unfolding temperature, due to an earlier active site denaturation. Consequently, further research has to be performed in order to design thermostable variants that maintain their activities at elevated temperatures [61].

The DS bond, which is observed only in bacterial cutinases (DS1, Figure 2B) anchors the C-terminal to the central region of the enzymes. This bond has been shown to contribute to the thermodynamic and kinetic stability of leaf-branch compost metagenome-derived cutinase (LC-cutinase with PET-degrading activity [57]. In addition, the higher thermotolerance of AoC, when compared to its fungal counterpart, $\mathrm{FsC}$, has been attributed to an additional DS bond, which is 
unique for the cutinases from the Aspergillus family [47]. The thermostability of many bacterial cutinases has also been attributed to the presence of calcium ions $[57,58]$. Based on the available structural data, these ions are not prosthetic groups of the active site, nor do they actively participate in the hydrolytic reaction. Est119 from Themobifida alba was significantly stabilized by calcium ions bound on the protein surface, without affecting its secondary structure [32]. The only cutinase whose structure is significantly altered upon calcium binding is Cut190 from Saccharomonospora viridis. Its calcium-bound crystal structure revealed that the occurrence of calcium ions not only reduces the mobility of flexible regions, but it also stabilizes an open conformation of the active site, allowing the substrate to bind easily [58]. Recently, it was also demonstrated that the presence of calcium ions accelerated the opening of substrate binding pocket, allowing for the fast release of the substrate hydrolysis products and the binding of a new substrate molecule [62].

\subsection{Structural Determinants of Cutinase Activity}

Many studies have attempted to relate the substrate preferences of cutinases to their structural characteristics, with the aim to engineer biocatalysts of desired properties. The varying hydrolytic efficiency of cutinases against different polymers has been attributed to their distinct electrostatic and hydrophobic surface properties [41,59]. Two highly homologous Thermobifida cellulosilytica cutinases, Thc_Cut1 and Thc_Cut2, which differ significantly in their capacity to degrade PET, allowed for the examination of how surface amino acids affect cutinase function. In specific, Thc_Cut2, which displays significantly lower PET degrading ability than Thc_Cut1, was mutated based on the nature of amino acids occurring on Thc_Cut1 surface. It was shown that an exchange of a positively charged residue by a non-charged amino acid strongly increased the activity of Thc_Cut2 against the PET model substrate bis(benzoyloxyethyl) terephthalate (3PET) and PET. In addition, the exchange of uncharged Gln to negatively charged Glu led to a complete loss of activity on PET films [63], underlying the importance of surface charge properties for the functionality of cutinases. The same effect was observed for the hydrolysis of the aliphatic polyester poly(lactic acid) (PLLA) by T. cellulosilytica cutinases [59].

Ideonella sakaiensis 201-F6 is a recently discovered bacterium with the unique capacity to use PET as a carbon and an energy source [64]. This bacterium secretes a PET-hydrolyzing enzyme, which exhibits high homology to cutinases. However, it has been categorized into a novel family of enzymes, named PETases, because of its increased PET-degrading capacity, and its lower activity against aliphatic esters, which constitute preferred substrates for cutinases and lipases. Since the discovery of this enzyme, many groups have performed structural studies in order to determine the structural characteristics that contribute to its increased PET degrading capacity [39,65-67]. According to their findings, PETase adopts a classical $\alpha / \beta$ hydrolase fold, with a core consisting of eight $\beta$-strands and six $\alpha$-helices (Figure 2C). Its closest structural homolog is T. fusca cutinase [38]. PETase has a highly polarized surface charge, whereas cutinases display patches of negative and positive charges, resulting in a more neutral pI. In addition, it has a wider substrate binding groove compared to cutinases. Since the majority of amino acids forming the substrate binding groove are conserved among homologous enzymes, this difference has been attributed to different factors, among which is the increased mobility of a conserved tryptophan residue, which is only observed in the PETase structure [68]. A neighboring serine (which corresponds to histidine in homologous structures) allows for the increased mobility of this tryptophan, which is crucial for substrate binding. In addition, PETases have two DS bonds, contrary to homologous enzymes that feature only one conserved DS bond (Figure 2B,C). The additional DS bond in PETases links two loops that harbor the catalytic base and catalytic acid respectively. One of these loops, the one harboring the catalytic base, named $\beta 8-\alpha 6$ loop, is longer in PETases. It has been suggested that the additional DS bond is required to maintain the catalytic triad, and the extended loop to their functional locations [68]. In addition, a PETase variant without this DS bond had a significantly higher $T_{\mathrm{m}}$ compared to WT (46.8 vs $33.6^{\circ} \mathrm{C}$ ), indicating the importance of this bond for the thermostability of the enzyme [65]. Based on the architecture of cutinase active site, Austin et al. mutated two residues in order to create a narrower 
cleft, while mutated the flexible tryptophan residue to alanine [67]. Contrary to what was anticipated, the mutated enzyme outperformed the WT in the degradation of semi-aromatic polyesters, such as PET. The aforementioned structural studies will pave the way towards the successful protein engineering of enzymes with enhanced activity and stability for PET degradation applications.

\section{Improving the Heat and Operational Stability of Cutinases}

As already mentioned above (Section 3.1), stability, and especially heat stability, is a very important feature for a biocatalyst. This property is highly appreciated for industrial applications, where enzymes are expected to work extensively at temperatures of around $50{ }^{\circ} \mathrm{C}$ [69]. Furthermore, heat tolerance is positively associated with other kinds of protein stability, such as tolerance in organic solvents [70], which is also an important property for cutinases that are utilized for synthetic chemistry applications. There are only a few heat-stable cutinases characterized so far, and they all originate from thermophilic microorganisms, such as T. fusca [43], H. insolens [49], and M. cinnamomea [51] (Table 1). Nevertheless, not all cutinases from thermophilic sources have proven to be thermostable, for example, MtCUT from M. thermophila [52]. Due to the above, several efforts have been made to increase the heat and operational stability of cutinases using molecular biology or immobilization tools.

\subsection{Host Selection and Protein Engineering Techniques}

Selection of a suitable heterologous host is a first step for the proper expression of a functional and stable protein. Nikolaivits et al. studied the effect of the bacterial host (E. coli BL21 and Origami 2), along with the localization of the protein folding (cytoplasmic and periplasmic) for the expression of a more thermostable F. oxysporum cutinase [22]. A 3-fold increase of thermostability was observed at $35{ }^{\circ} \mathrm{C}$ for the cytoplasmic product of the Origami strain, compared to the respective one of the BL21 strain. In the case of $G$. cingulata cutinase, a 2.7 -fold increase of stability at $35^{\circ} \mathrm{C}$ was observed when it was expressed in a eukaryotic host like P. pastoris [50], instead of E. coli Origami B [71]. P. pastoris has been indeed proven to be a proper host for the expression of fungal cutinases, such as in the case of $T$. terrestris, which showed a $3{ }^{\circ} \mathrm{C}$ higher $T_{\mathrm{m}}$ compared to when it was expressed in E. coli DH5 $\alpha$ [72]. The higher thermotolerance was attributed to the glycosylation modification occurring in the eukaryotic host. The theory that glycosylated proteins are more heat-stable than their non-glycosylated variants was further verified, when a bacterial cutinase (LC-cutinase) was expressed in P. pastoris, in order to produce a glycosylated variant that exhibited an $10{ }^{\circ} \mathrm{C}$ increase in its thermally induced aggregation temperature [73]. The effect of glycosylation was also verified through the engineering of a glycosylation site on A. oryzae cutinase (AoC), resulting in a 4-fold higher $\mathrm{t}_{1 / 2}$ at $61{ }^{\circ} \mathrm{C}$ compared to the WT analogue [74].

Protein engineering techniques have also been applied in order to increase the thermostability of cutinases. G. cingulata single mutants aiming at the removal of an asparagine prone to deamination [71] and in increasing the rigidity of the structure [75], led to enhanced thermostability. TfCut2 from T. fusca has been shown to increase its $T_{\mathrm{m}}$ by $13{ }^{\circ} \mathrm{C}$, through the addition of $10 \mathrm{mM} \mathrm{Ca}^{2+}$ [76]. The binding site of calcium cations on the cutinase structure was identified and altered, so that a single mutant was created with no need of dication for its increased thermostability, leading to a $15^{\circ} \mathrm{C}$ higher $T_{\mathrm{m}}$ compared to WT. Shirke et al. performed a mutational analysis on AoC, testing various types of mutations and their effects on thermostabilization and activity [61]. A septuple mutant with $6{ }^{\circ} \mathrm{C}$ higher $T_{\mathrm{m}}$ than the WT AoC was managed to be created, exhibiting a 13-fold higher $\mathrm{t}_{1 / 2}$ at $60^{\circ} \mathrm{C}$.

\subsection{Immobilization}

The utilization of an immobilized biocatalyst presents many advantages for industrial applications. The most important is the increase of the operational stability, and hence the reusability of the biocatalyst, which reduces the cost of an industrial process. There are several immobilization methods on various types of solid supports that are achieved by adsorption, entrapment, and non-covalent and covalent binding [77]. The immobilization of enzymes may affect properties other than their stability, 
namely, activity, specificity, or selectivity. These changes can sometimes be associated with alterations in the enzyme structure, but could also be an outcome of incidental enzyme modifications, that are only beneficial for a specific type of reaction. Immobilization is a multiparametric process, and it is not easy to predict whether the resulting biocatalyst will be suitable for a particular application $[78,79]$.

F. solani cutinase $\mathrm{FsC}$ has been immobilized on a triazine-based affinity ligand, which was synthesized in agarose. The immobilized catalyst showed an impressive 57 -fold increase of $t_{1 / 2}$ at $60{ }^{\circ} \mathrm{C}$, compared to the free enzyme [80]. Another Fusarium cutinase adsorbed onto chemically modified gold nanoparticles was used for river and tap water detoxification, with the ability to be reused up to five times [81]. Su et al. studied the immobilization of three cutinases from A. oryzae, $H$. insolens, and T. terrestris through adsorption on a commercial macroporous support (Lewatit VP OC 1600) [82]. The immobilized enzymes showed increased optimal temperatures of $75{ }^{\circ} \mathrm{C}$, and superior thermostability (stable at $70{ }^{\circ} \mathrm{C}$ for $1 \mathrm{~h}$ ) with regard to their free forms. Kumari et al. synthesized a chitosan-co-chitin polymer grafted with polyacrylamide for the adsorption of an Aspergillus sp. cutinase [83]. The immobilized catalyst showed an increase in $\mathrm{T}_{\mathrm{opt}}$ by $10^{\circ} \mathrm{C}$, and a 2-fold higher $\mathrm{t}_{1 / 2}$ at $40{ }^{\circ} \mathrm{C}$. Thc_Cut1 from T. cellulosilytica was ionically bound to Fe(III)-activated carriers taking advantage of its His-tag. The catalyst was capable of being reused up to three times for the synthesis of polybutylene adipate oligomers [84]. Other than chemically synthesized materials, there are some reports of naturally-occurring polysaccharides that have been utilized as immobilization supports. Cutinase from a Fusarium strain has been immobilized on pectin and chitosan. Non-covalent immobilization on pectin resulted in a biocatalyst with 1.4 -fold higher $\mathrm{t}_{1 / 2}$ at $40{ }^{\circ} \mathrm{C}$ [85]. Both non-covalent and covalent binding on chitosan were studied, leading to more thermostable biocatalysts, with higher increases for the covalently bound cutinase [86]. T. fusca cutinases have also been covalently immobilized on glutaraldehyde-activated chitosan beads, exhibiting increased thermostability at $55^{\circ} \mathrm{C}$ [87]. Cationic lignin nanospheres have been used for the adsorption of $H$. insolens cutinase (HiC), and they were further entrapped in sodium alginate beads [88]. The resulting catalyst could be used a few times for the synthesis of butyl butyrate, and its $t_{1 / 2}$ under the specific reaction conditions was higher compared to the literature.

Carrier-free immobilization procedures by the cross-linking of proteins have proven to be a cheaper alternative, since the high cost of carriers is circumvented [77]. Cross-linked enzyme aggregates (CLEAs) are usually prepared by the cross-linking of precipitated enzyme preparations using glutaraldehyde. An example carried out by Chaudhari and Singhal [89] was performed to reduce the overall cost of creating a stable biocatalyst. Watermelon rinds were utilized both as an energy source and an inducer of cutinase activity from Fusarium sp., and the culture broth was directly immobilized by CLEAs methodology. Cut-CLEA presented a higher $\mathrm{T}_{\text {opt }}$ by $10{ }^{\circ} \mathrm{C}$, and retained its activity at $60^{\circ} \mathrm{C}$ after $1 \mathrm{~h}$, while the free enzyme was stable up to $40^{\circ} \mathrm{C}$. Furthermore, the immobilized cutinase increased its stability in organic solvents, and especially in polar ones. A recombinant F. oxysporum cutinase was also immobilized following CLEA methodology using the crude intracellular fraction of the E.coli host [90]. Its thermostability increased 3-fold at $35^{\circ} \mathrm{C}$, and it could be reused for the synthesis of butyl butyrate up to four times, with less than $50 \%$ reduction of yield.

\section{Environmental Biocatalysis}

Biodegradation constitutes an eco-friendly and economic approach for polymer waste management, and it is gaining ground as a viable remediation process for industrial applications. Cutinases have prevailed in terms of polyester treatments. In this respect, a better understanding of the enzyme-substrate binding interactions and the enzyme mode of action is essential for the purpose of engineering cutinases with enhanced activities, and for developing polymer modification strategies.

\subsection{Plastics Degradation}

Plastics comprise polymeric materials of significant interest, due to their features, such as low cost, light weight, satisfactory mechanical and thermal properties, and ease in processing and 
manufacture [91]. Therefore, plastics play a predominant role in our everyday life, spanning several application areas, from packaging, furnishing and transportation, to agriculture and the textile industry [92-95]. However, concerns have arisen pertaining to the environmental impact of the accumulating disposed waste that will ensue when the lifecycle of plastic products comes to an end. Based on current production and waste management trends, it has been estimated that approximately $12,000 \mathrm{Mt}$ of plastic waste will end up in landfills or the in natural environment by 2050 [96]. Due to their high recalcitrance, the development of degradation strategies is rendered imperative. Considering the aforementioned prediction, biocatalytic degradation constitutes a promising, eco-friendly, and economical waste management approach, since chemical depolymerization requires toxic chemicals and high temperatures [97]. To date, cutinases and their homologues are potential tools towards polymer degradation, since they have been reported to hydrolyze a variety of polymeric substrates, such as poly(butylene succinate) (PBS), polycaprolactone (PCL), and PET. Such examples have been recapitulated previously [98]. Below, the most recent cutinase depolymerization paradigms are epitomized.

\subsubsection{Degradation of Succinate Polyesters}

PBS is a thermoplastic polymer that exhibits balanced mechanical properties and satisfactory thermal processability, whereas its biodegradability can be regulated through copolymerization. PBS finds numerous applications in industries, ranging from packaging to biomaterials. Hydrolysis of PBS films was actuated by the use of a recombinant cutinase from $F$. solani with achieved weight loss in the vicinity of approximately $80-90 \%$, depending on the polymer molecular weight, after $48 \mathrm{~h}$ of incubation at $37^{\circ} \mathrm{C}$ [99]. The same scientific group prepared PBS blends with microcrystalline cellulose and cellulose acetate, and achieved $85 \%$ weight loss after $4 \mathrm{~h}$ of enzymatic reaction at $37^{\circ} \mathrm{C}$ [100]. Bai and coworkers studied the enzymatic degradation of poly(ethylene succinate) (PES), PBS, and poly(hexylene succinate) (PHS) by a F. solani cutinase [101]. Depending on the hydroxyl monomer of each polymer, the distance between the ester bonds differed in each case. Cutinase demonstrated a preference for hydrolysis in the order of PHS > PBS > PES, with weight losses of 88, 76, and $60 \%$ after $4 \mathrm{~h}$, and 100,98 , and $95 \%$ after $12 \mathrm{~h}$ at $37^{\circ} \mathrm{C}$, respectively. Moreover, a crude cutinase-like enzyme of yeast Pseudozyma antarctica has been reported to completely degrade polybutylene succinate-co-adipate (PBSA) film in $3 \mathrm{~h}$ at $30^{\circ} \mathrm{C}$, PBS, and poly(butylene adipate-co-terephthalate) in $24 \mathrm{~h}$ [102]. The production of this enzyme was stimulated by the use of xylose as a carbon source in a fed batch bioreactor.

\subsubsection{Degradation of PCL}

PCL is a thermoplastic aliphatic polyester with tunable mechanical properties and ease in manufacturing. Because of its biocompatibility, PCL is used in various biomedical applications. An extracellular cutinase of Pseudozyma japonica sp. nov. hydrolyzed PCL films by $93 \%$ at 15 days [103], while a cutinase from Aspergillus fumigatus achieved complete PCL degradation, presenting promising results for both biosynthesis and biodegradation [104]. Another group suggested the hydrolysis of PCL films by Bacillus sp. isolated from plastics waste water, exhibiting cutinase activity, where a weight loss of $77 \%$ was achieved at $30^{\circ} \mathrm{C}$ for 10 days of incubation [105]. Yang et al. reported the hydrolysis of PCL by a cutinase from $M$. thermophila (MtCUT), achieving a weight loss of $79 \%$ in $36 \mathrm{~h}$ [52].

\subsubsection{Degradation of PET}

PET is one of the most commonly used commodity polymers, and current research has focused on its post-consumer recycling strategies to decrease the discharged waste in the ecosystem. The degradation process depends on parameters such as the reaction temperature, the polymer's particle size and crystallinity, and the inhibition that the hydrolysis products may cause.

The cutinase Thc_Cut1 was examined for the hydrolysis of PET moieties in polymer blends originating from commercial bottles and packaging materials [106]. The hydrolysis of polymer blends 
met a 9-fold increase compared to pure PET with higher crystallinity. During this investigation, a 10 -fold increase of hydrolysis products was noted when the temperature shifted from $40^{\circ} \mathrm{C}$ to $60^{\circ} \mathrm{C}$. Furthermore, smaller particle size PET was hydrolyzed to a higher extent, while semi-crystalline PET from bottles exhibited a 2-fold degradation (24\%), as opposed to powdered amorphous PET. Hydrolysis product bis(2-hydroxyethyl) terephthalate (BHET) seemed to inhibit further PET hydrolysis. Thereby, a balanced strategy must be developed in order to reach the most favorable outcome in terms of polymer degradation yield, environmental footprint, and process cost. Cutinase Thc_Cut1 has also been tested on PET hydrolysis in combination with sonication treatment. The ultrasound-enhanced enzymatic process led to a 6.6-fold increase of the released degradation products compared to the untreated PET, whereas extended sonication times led to partial enzyme inactivation. An increase of crystalline percentage (28\%) in PET powder and films resulted in lower hydrolysis yields [107].

Semi-crystalline PET exhibits a high $T_{\mathrm{m}}$, which is inhibitive for enzyme activity, because of its aromatic building block unit, terephthalic acid. Enzymatic hydrolysis would prove feasible when occurring near the $T_{g}$ (over $70^{\circ} \mathrm{C}$ ); at this temperature, the chains in the amorphous regions obtain flexibility [108]. Remarkably, however, I. sakaiensis PETase has been demonstrated to degrade PET at $30{ }^{\circ} \mathrm{C}$, while it has exhibited a preference for PET to aliphatic esters, rendering it an aromatic polyesterase. This mesophilic enzyme exhibited 6-120-fold higher activity against PET films compared to the three holomogues: TfH from a thermophilic actinomycete, LC-cutinase, and FsC [64]. PETase has also presented enhanced activity against commercial bottle-grade PET. Fecker and coworkers demonstrated that the enzyme active site presents higher flexibility at room temperature, attributable to a novel disulfide bond that stabilizes the catalytic triad [66].

PET depolymerization leads to the corresponding building blocks, usually including mono(2-hydroxyethyl) terephthalate (MHET), which has been reported to inhibit the enzyme activity [109]. In this respect, it is reported in the literature that PET treatment in monoethylene glycol solvent with HiC promotes BHET synthesis as the main depolymerization product. BHET, which is typically produced chemically at high temperatures, can be processed further in a posterior stage for PET synthesis anew, reassessing the cost and environmental footprint of the procedure [110]. It was subsequently evidenced that PET treatment in ethylene glycol/buffer media with the same biocatalyst provides tunability towards adjunct PET depolymerization products [111].

\subsubsection{Degradation of Polyethylene Furanoate}

Recently, polyethylene furanoate (PEF), consisting of sugar-derived 2,5-furandicarboxylic acid (FDCA) as a building block, has emerged as a biobased polymer. This polymer exhibits improved mechanical and gas barrier properties in comparison to PET, and thus it has raised industrial interest. The depolymerization of PEF powders with different molecular masses, crystallinities, and particle sizes has been reported, using cutinase Thc_cut1 [112]. It was shown that amorphous particles of lower molecular mass are hydrolyzed faster and to a greater extent compared to high molecular weight and crystalline ones. Amorphous PEF films were completely degraded to FDCA and water-soluble oligomers by HiC cutinase, whereas Thc_cut1 resulted in up to $55 \%$ hydrolysis under the same reaction conditions. In a following step, the degradation of amorphous and crystalline PEF and PET films by Thc_cut1 and HiC was examined [113]. PEF films were hydrolyzed to a greater extent, while it was confirmed that enzymatic hydrolysis was conversely affected by the increase of the crystallinity of the tested material.

\subsubsection{Degradation of Other Synthetic Polymers}

Polyurethanes are synthetic polymers that are used in numerous sectors such as in the production of foams, adhesives, and coatings. According to the literature, cutinase treatment has been attempted for the degradation of polyester polyurethanes [114]. A LC-cutinase caused a $4-5 \%$ weight loss for Elastollan B85A-10 and C85A-10 within $200 \mathrm{~h}$ at $70^{\circ} \mathrm{C}$. 
Thermosetting polymers exhibit high strength and stability at high temperatures; therefore, they are applied in automotive, furniture, and building industries, and in other fields. Hou and coworkers pinpoint the enzymatic degradation of ring opening metathesis polymerization (ROMPR) thermosetting materials, incorporated with acetal ester groups in the crosslinking moiety, catalyzed by Thc_Cut1 cutinase from T. cellulosilytica [115]. The insoluble cross-linked materials were treated enzymatically, and they became completely soluble in dichloromethane. Thc_Cut1 efficiently degrades the acetal-ester crosslinks, converting the insoluble crosslinked ROMP thermosetting materials into linear, soluble polymers under mild reaction conditions.

Another study describes the hydrolysis of poly(oxyethylene terephthalate) (PET-PEO) by an enzyme mixture of an esterase and a cutinase from Pseudomonas pseudoalcaligenes, and a lipase from Pseudomonas pelagia, in order to facilitate further degradation of the material in wastewater treatment plants (WWTP) [116]. It is common to introduce polymers with polyoxyethylene chains in order to regulate their characteristics, such as crystallinity, glass-transition temperature, flexibility, water solubility, and adsorption onto hydrophilic surfaces. The hydrolase mixture depolymerized PET-PEO to an extent. and maintained an activity of up to $50 \%$ when temperature was decreased from 28 to $15^{\circ} \mathrm{C}$, in order to mimic WWTP conditions. Microorganisms that express such enzymes could prove to be an indispensable tool for the biological treatment of wastewater containing synthetic polymers; however, they are far from a panacea, since hydrolysis products may cause enzyme inhibition, and such issues must be handled.

\subsection{Engineering Cutinase Depolymerization Activity}

Enzymatic depolymerization constitutes a promising process for the treatment of post-used synthetic polyesters that otherwise accumulate in the ecosystem, due to their usage in a plethora of applications. The key challenge of enzymatic degradation of synthetic polyester materials is the engineering of novel enzymes, through protein engineering routes, with enhanced thermal stability or tuned specificity that is designed to address different polymeric substrates.

Cutinase adsorption onto polyester surfaces could be improved by the presence of exogenous binding modules, such as small hydrophobic proteins, termed hydrophobins, which are secreted by filamentous fungi. Hydrophobins consist of eight cysteine residues, which are responsible for adsorption onto hydrophobic surfaces [117]. In an attempt to increase cutinase activity, class II hydrophobins HFB4 and HFB7 from Trichoderma spp. were covalently fused to cutinase Thc_Cut1, achieving a 16-fold increase of the produced products from PET hydrolysis, in comparison to the free enzyme [118]. Other studies have focused on the structural elucidation of the cooperative ionic interaction between hydrophobin RodA and polyesterase CutL1 of fungus A. nidulans towards sorption onto PBSA surface [119-121].

In another approach, cutinase Thc_Cut1 was fused with two different binding modules to improve sorption on polymer substrate ensuing hydrolysis [122]. The binding domains derived from cellobiohydrolase I from Hypocrea jecorina (carbohydrate binding module, CBM) and from polyhydroxyalkanoate depolymerase from Alcaligenes faecalis (polyhydroxyalkanoate binding module, PBM), manifest a common interaction mechanism involving hydrophobic interactions via tryptophan residues. The fusion enzymes demonstrated improved hydrolysis activity towards PET, however, presented a different pattern regarding the acquired degradation products.

Furthermore, the synthesis of variants through mutation routes has proven to be of paramount importance for the activity enhancement of cutinases, as hydrolytic tools that target plastic depolymerization. Wei and coworkers reported the production of two variants from cutinase TfCut2, G62A and G62A/I213S, that elicited more than $42 \%$ weight loss of PET films after $50 \mathrm{~h}$ at $65{ }^{\circ} \mathrm{C}$, corresponding to a 2.7-fold increase of enzyme activity compared to the WT [123]. This is elucidated by the fact that TfCut2 variants were less inhibited by MHET, compared to the WT. Mutational analysis of a cutinase from the thermophile S. viridis showed that the substitution of Ser226 with Pro for increased structural rigidity, and that the substitution of Arg228 with neutral Ser, as well as the 
addition of $\mathrm{Ca}^{2+}$, improved the enzyme's activity and thermostability, based on a PBSA hydrolysis assay [124]. The variant displayed activity on the polyester-agar plates, including PBSA, PBS, PCL, aliphatic-co-aromatic polyester Ecoflex ${ }^{\circledR}$, PHB, poly(D-lactic acid) (PDLA), and poly(L-lactic acid) (PLLA). Hydrolysis of amorphous PET at $63^{\circ} \mathrm{C}$ resulted in a weight loss of $14 \%$, whereas the hydrolytic effect was almost twice that for PET package material. In the study of Zhang et al., a cutinase-CBM ${ }_{\text {CenA }}$ fusion protein was genetically modified in the binding sites of the CBM [125]. Mutants W68L and W68Y showed 1.5-fold increased binding and catalytic efficiency toward PET fibers in contrast to the native enzyme, which is possibly attributed to the formation of hydrogen bonds or hydrophobic interactions between the cutinase and the PET substrate.

Austin and coworkers reported that changes in the active site of I. sakaiensis PETase pertinent to T. fusca cutinase architecture improved its degradation capacity towards PET [67]. The PETase variant was employed for the degradation of PET of higher crystallinity $(\sim 15 \%$, bottle-grade) and PEF. An I. sakaiensis PETase mutant was also constructed by substituting Arg280 into a small hydrophobic residue, achieving enhanced PET degradation ability by $22 \%$ and $32 \%$ in $18 \mathrm{~h}$ and $36 \mathrm{~h}$, compared to the WT [65]. Another group observed activity increments against bottle-grade PET, due to mutations that enlarged the substrate binding site or that increased the aromaticity on the edge of the binding pocket [126]. On the contrary, the same study showed that a series of mutations targeting the substrate binding pockets, the catalytic residues, as well as the residues involved in stabilizing the rigidity of the active site, decreased or even extirpated the enzyme activity.

\subsection{Effect of Medium Components and Synergistic Interaction in Cutinase Depolymerase Activity}

Apart from protein engineering approaches, a strategy to improve enzyme thermostability or/and enzyme activity is the addition of metal ions to the corresponding binding sites of the enzyme, in order to prevent unfolding of the catalytic site at higher temperatures. Then and coworkers reported that cutinase TfCut2 from T. fusca in the presence of $10 \mathrm{mM} \mathrm{Ca}^{2+}$ or $\mathrm{Mg}^{2+}$ exhibited ameliorated thermostability and PET degradation, with weight losses of up to $13 \%$ for a $48 \mathrm{~h}$ reaction time, while the three cation-binding residues were identified [76]. Accordingly, in the study of Suzuki et al. the presence of $\mathrm{Ca}^{2+}$ increased by 3-fold the activity of Paraphoma-related fungus cutinase-like enzyme against emulsified PBSA, as opposed to $\mathrm{Mg}^{2+}$ [28]. A recombinant $F$. solani cutinase showed increased activity towards PBS hydrolysis in the presence of $10 \mathrm{mM} \mathrm{K}^{+}$and $\mathrm{Na}^{+}$, whereas the addition of $\mathrm{Zn}^{2+}$, $\mathrm{Fe}^{2+}, \mathrm{Mn}^{2+}$, and $\mathrm{Co}^{2+}$ led to impaired enzyme effectiveness [127].

The biocatalytic depolymerization of post-consumer polymeric materials as a recycling route, is a promising "green" approach. However, the resultant degradation products, such as BHET, MHET, or ethylene glycol, can render an inhibitory factor for enzyme hydrolytic performance $[109,128]$. To this respect, the synergistic action of Candida antarctica lipase B (CALB) and HiC was investigated, and an 8-fold increase in conversion of amorphous PET films to terephthalic acid was achieved, compared to single HiC activity [129]. This protein mixture is also suggested for PET bottle film hydrolysis, achieving a 2.2-fold increase in the product titers, as opposed to each of the two enzymes when used alone [130]. A cutinase variant from T. fusca, TfCa was utilized in combination with a metagenome-derived LC-cutinase for PET film degradation [131]. TfCa was immobilized on SulfoLink resin to increase its thermostability. The dual enzyme system led to a 2.4-fold higher production of degradation moieties compared to a cutinase from T. fusca, TfCut2, while TfCa in the protein mix led to impaired inhibitory MHET concentration in the hydrolysis products.

An alternative study justified that the hydrolytic activity of LC-cutinase from a compost metagenome, and TfCut2 from T. fusca KW3 depended on the type, strength, and molarity of the reaction medium [132]. Sodium phosphate buffer seemed to provide $\mathrm{pH}$ stabilization for the reaction, while a buffer at a concentration of over $0.7 \mathrm{M}$ obtained the highest initial hydrolysis rates. On the contrary, 3-(N-morpholino)propanesulfonic acid (MOPS) and tris(hydroxymethyl)aminomethane (Tris) buffers diminished cutinase activity, with MOPS eliciting stronger inhibition, according to the $\mathrm{K}_{\mathrm{i}}$ values and the average binding energies. 


\subsection{Other Bioremediation Applications}

The hydrolytic activity of cutinases against a wide spectrum of substrates with varying molecular weights has rendered this class of enzymes as useful biocatalysts for the degradation of compounds other than polymers. This activity can be used to cleave any ester bond-containing pollutant, and it can be applied in the deinking of paper, and the degradation of phthalate esters and toxins.

Deinking is a part of the printed paper recycling process, and it concerns the removal of printing ink from the paper pulp fibers. This process is performed industrially through harsh alkali treatment $\left(\mathrm{NaOH}, \mathrm{Na}_{2} \mathrm{SiO}_{3}, \mathrm{EDTA}, \mathrm{H}_{2} \mathrm{O}_{2}\right)$, thus creating harmful wastewaters. An alternative to chemical deinking is the use of enzymes, most commonly cellulases, hemicellulases, and laccases [133]. Cutinases could be used in this process, due to their ability to hydrolyze the ester bonds in natural/synthetic resins, and polyesters used in ink vehicles hydrolyze the triglycerides in vegetable oil-based inks and deacetylate polyvinyl acetate (PVAc), an adhesive that is used in paper-making and in synthetic toner or ink. Wang et al. used biodegradable surfactants and compared the traditional chemical treatment with the enzymatic treatment of office wastepaper consisting of laser-printed and photocopied paper [134]. Alkaline treatment resulted in 92\% ink removal and $90.5 \%$ ISO brightness. When cutinase from T. fusca $(10 \mathrm{U} / \mathrm{g})$ was applied for $30 \mathrm{~min}$ in neutral $\mathrm{pH}$ and $50{ }^{\circ} \mathrm{C}, 91 \%$ ink removal and $91.6 \%$ ISO brightness were achieved. Cutinase, in combination with amylase $(5 \mathrm{U} / \mathrm{g})$, led to better results than alkali treatment (92.6\% ink removal and $92.2 \%$ ISO brightness). Furthermore, tensile and tear indexes properties of the resulting deinked pulp were better in the case of the enzymatic treatment. T. fusca cutinase has also been used for the deinking of old newspaper in comparison with FsC [135]. The two enzymes acted in different conditions ( $\mathrm{pH} 8$ and $60^{\circ} \mathrm{C}$ for TfC; $\mathrm{pH} 8.5$ and $35^{\circ} \mathrm{C}$ for $\mathrm{FsC}$ ) for $30 \mathrm{~min}$, resulting in a deinked pulp with a brightness of close to $42 \%$. This result was better than the one obtained by commercial lipase (CrLIP from Candida rugosa) and by chemical treatment, but worse than the aforementioned work of Wang et al. The cutinase from $M$. thermophila with confirmed activity on PVAc was tested for the deinking of laser-printed paper and old newspaper [52]. Reactions with MtCUT were conducted in $\mathrm{pH} 7.5$ at $30^{\circ} \mathrm{C}$ for $3 \mathrm{~h}$, and they resulted in ink removal rates of close to $80 \%$ for both types of paper. Liu and coworkers studied the efficiency of T. terrestris cutinase and Thermomyces lanuginosus lipase for the deinking of laser-printed paper and newspaper pulps [136]. Researchers first noticed that even though lipase had very low activity on PVAc, there seemed to be a synergistic effect between the two enzymes. Thus, they created a chimeric lipase-cutinase enzyme through end-to-end fusion via a linker peptide. This chimeric protein showed an even higher deacetylation efficiency of PVAc. The deinking reaction took place at $\mathrm{pH} 8,40{ }^{\circ} \mathrm{C}$, and led to ink removal rates of $88 \% / 85 \%$ and a brightness of $59 \% / 85 \%$ for laser-printed paper/newspaper, respectively. Furthermore, the enzymatic degradation of poly(methyl acrylate) and poly(ethyl acrylate) by cutinases from H. insolens, F. solani, and T. fusca has recently been indicated, since polyacrylates tend to accumulate during waste paper recycling process, diminishing the quality of the recycled paper [137].

Phthalate esters are widely used chemicals in plastic manufacturing, and as additives in polyvinyl chloride (PVC) materials, paints, lubricants, adhesives, and cosmetics, among others. They are released into the environment through the wastewaters of industries, or by disposal of the products containing them (e.g., children's toys) and there are reports that show possible adverse health effects in human health [138]. Cutinases can break the ester bond of these compounds as a first step towards their bioremediation. Several studies have been performed that underline the ability of a F. oxysporum cutinase to hydrolyze several phthalates, such as dipropyl [139], dibutyl [140], dipentyl [141], dihexyl [142], butyl benzyl [143], and di(2-ethyl hexyl) [144] phthalates. Degradation yields of over $60 \%$ were achieved in all cases in less than $7.5 \mathrm{~h}$ and the detected hydrolysis product was the non-toxic 1,3-isobenzofurandione (phthalic anhydride). Zhang et al. studied the hydrolysis of bis(2-ethyl hexyl)phthalate (DEHP), along with the adsorption of $\mathrm{Pb}$ (II) by a cutinase immobilized on gold nanoparticles at $25^{\circ} \mathrm{C}$ and pH 7.0 [81]. Removal yields were over $90 \%$ in $10 \mathrm{~h}$, in which enzymatic hydrolysis contributed over $80 \%$. 
Cutinase detoxification of toxin-containing feed has also been described in two patents by Novozymes AS $[145,146]$. One patent describes the use of cutinase for the hydrolysis of zearalenone, which is produced by some Fusarium species. The hydrolysis of zearalenone reached $81 \%$ after $24 \mathrm{~h}$ at $37^{\circ} \mathrm{C}$. The second patent is about the biotransformation of aflatoxin, which was degraded by $38 \%$ under the above-mentioned conditions at $\mathrm{pH}$ 7. These toxins contain one ester bond in their structure, which is supposed to be hydrolyzed by cutinase enzymes. However, one important aspect of this biotransformation is neglected, which is the determination of toxicity for the resulting products. Another environmental application of cutinases in agriculture could be the hydrolysis of insecticides. For example, the utilization of $F$. oxysporum cutinase for the degradation of organophosphate insecticide malathion was studied [147]. Malathion is a diester of dutanedioic acid, and it is the most frequently used organophosphate pesticide in the US. Cutinase could hydrolyze both ester bonds at $60 \%$ yields, and finally produce the non-toxic malathion diacid after 2 days.

\section{Superficial Functionalization of Polymers}

Apart from enzymatic treatment in terms of plastic waste management, cutinases can also be utilized for polymer functionalization, aiming at improved or altered final properties. Polymers such as PET and PLA present intrinsic hydrophobicity and inertia, which can prove to be limiting for certain applications. Enzymatic polymer functionalization is an eco-friendly and less invasive-to the bulk material—approach towards the preparation of advanced products, since its limited surface hydrolysis leads to the release of active end groups. These functional groups increase polymer hydrophilicity, and they can subsequently be utilized for covalent binding to specific molecules, or enhanced adhesion of other materials.

\subsection{Surface Modification of PET}

Polyester fabrics occupy a great part of the textile industry; nonetheless, their high level of hydrophobicity is an impediment with regard to water permeability, the evaporation of sweat, and dyeing with reactive dyes. The treatment of such materials with cutinases has proven to be an eco-friendly procedure that aims at the increase of hydrophilicity through superficial modification, while avoiding harsh chemicals and reducing energy consumption. In this respect, enzymatic hydrolysis generates carboxylic and hydroxyl groups on the surface, due to ester bond cleavages, without affecting the bulk properties of the polymer.

The surface hydrolysis of polyester fabrics by the recombinant cutinase Cut $190^{*}$ from the actinomycete $S$. viridis has been reported [148]. The increment of carboxyl end groups on the fiber surface was detected with the cationic dye methylene blue, accomplishing the increase of the color strength $\mathrm{K} / \mathrm{S}$ by 25 and $28 \%$ for PET and Ecoface ${ }^{\circledR}$ fabrics, respectively. Furthermore, the enzymatically treated fabrics showed a water capillary rise, while their mechanical properties were not affected. To complement these results, our group performed a surface modification of PET fabrics with a recombinant cutinase from $F$. oxysporum, achieving a K/S increase of 140 and $150 \%$, after dyeing with the reactive dyes Novacron Yellow and Novacron Deep Cherry S-D [149]. Enzymatic treatment was carried out on the surface of the polymeric material, and as observed from X-ray photoelectron spectroscopy (XPS) analysis, no obvious effect was observed on the tensile and thermal properties of the modified fabrics. PET fabrics have also been treated by using a cutinase from T. fusca. The increased hydrophilicity of the modified PET fabrics was justified by water contact angle and dye uptake measurements of cationic Turquoise Blue and Brilliant Red dyes, reaching a 33\% improved dyeing efficacy [150]. Silva et al. investigated the surface hydrolysis of PET fabrics by two engineered cutinases from T. fusca, a single and a double mutant. The first mutation created more space around the active site, whereas the second mutation rendered the binding site more hydrophobic, and thus with improved substrate attachment. PET modification with the cutinase variants revealed a higher rate of TPA release in the reaction supernatant, and almost 2-fold enhanced colorization with the Reactive Black 5, comparing to the WT enzymatic activity [151]. 
A modification treatment catalyzed by a cutinase for a different application is described by Vecchiato and coworkers. This group utilized four cutinase variants from T. cellulosilytica to achieve surface activation of high modulus and low shrinkage poly(ethylene terephthalate) (HMLS-PET) for further functionalization through the adhesion of a carcass rubber for tire reinforcement applications [95]. Furthermore, the surface functionalization of amorphous PET foils, after treatment with $\mathrm{HiC}$ or oxygen plasma is described in the literature [152]. Plasma activation resulted in $19 \%$ higher release of carboxylic groups than the cutinase treatment. However, enzymatically hydrolyzed PET foils remained stable after one month of storage, whereas in plasma-treated PET, no carboxyl groups were detected, based on XPS analysis. In any case, the superficially hydrolyzed PET foils demonstrated increased chitosan coating adhesion. Chitosan is a cationic polysaccharide with antimicrobial properties, and such functionalized products could find potential applications in packaging. PET modification routes aiming at different applications is depicted in Figure 3.

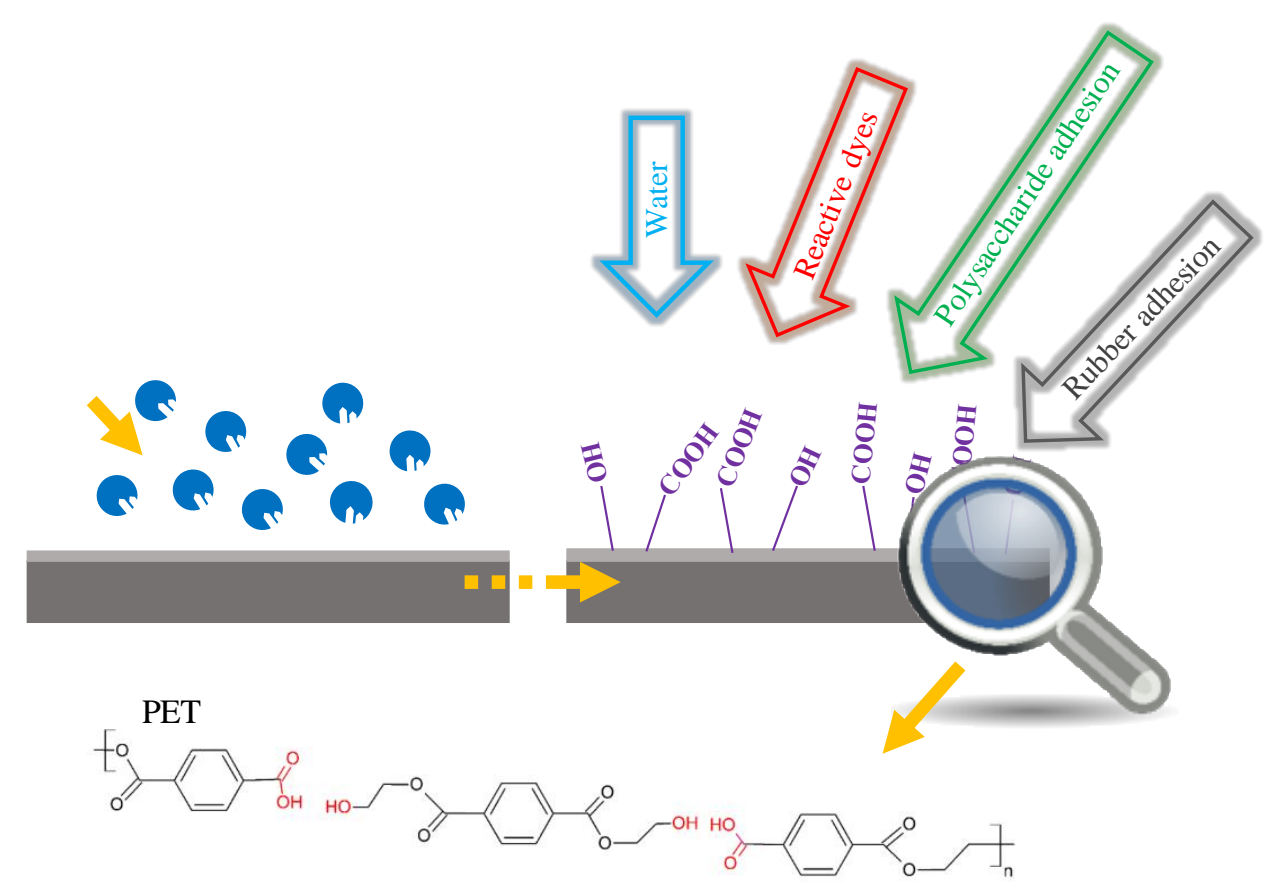

Figure 3. Enzymatic hydrolysis and functionalization of PET surface for various applications.

\subsection{Surface Modification of PLA}

PLA is a sustainable, biocompatible, and biodegradable polyester that has been extensively investigated for its application in food packaging, the textile industry, and biomedicine for drug delivery and tissue engineering platforms [153-156]. Nevertheless, the lack of reactive groups on the PLA surface obstructs further functionalization. The preparation of PLLA loaded with the chemotherapeutic drug doxorubicin is reported, with its potential use in grafts, with an anticancer effect. A hydrophilicity increase in PLLA films was noted, as a result of surface hydrolysis with $H$. insolens cutinase [157]. The enzymatic treatment led to surface activation with the generation of more carboxyl and hydroxyl groups, as a result of ester bond cleavages. Subsequently, the cationic doxorubicin was loaded onto the treated films through ionic interactions, and desorption studies took place. In another research report, the surface hydrolysis of PLA films is combined with coating of a stearic alkene ketene dimer through the formation of $\beta$-ketoester bonds, producing superhydrophobic materials for potential applications in microfluidics or biosensors [158]. 


\section{Cutinases as a Tool for Synthetic Chemistry}

The discovery by Zaks and Klibanov in 1984 [159] that lipases can act in organic media and catalyze transesterification reactions with enhanced thermostability changed the landscape in the field of non-conventional biocatalysis. Since then, numerous reports for the synthetic activity of esterolytic enzymes have been published.

Similar to lipases, cutinases can perform esterification, transesterification, and polycondensation reactions in the absence of water. Due to their preference for short or medium chain-length substrates, they have been widely utilized for the synthesis of flavor esters. Such esters commonly have chain lengths of less than 10 carbon atoms, and they are used by the food, cosmetics and pharmaceutical industries. Chemical synthesis can be cheap, but not environmentally friendly, since the reactions take place at high temperatures of around $150-240{ }^{\circ} \mathrm{C}$. Enzymatically, these compounds can be synthesized by esterification or transesterification reactions of fatty acids, or of their esters and alcohols, in organic solvents at temperatures of $25-50{ }^{\circ} \mathrm{C}$. The mechanism of these reactions follows the Ping Pong Bi model, and suffers from alcohol inhibition $[160,161]$. The yields for both types of reactions in non-conventional media, such as isooctane or heptane, are high in most cases $(>95 \%)[25,162]$. The highest yields for butyl butyrate synthesis have been achieved in isooctane by esterification using cutinase from $M$. cinnamonea (McCut) (97\%) [51], and by transesterification with cutinase from F. oxysporum (imFocut5a) (>99\%) [90]. In both cases the reactions reached equilibrium in less than $6 \mathrm{~h}$, but the amount of imFocut5a utilized was almost 20 times lower than the one of McCut.

An alternative reaction system for the esterification of medium-chain esters by FsC was developed, creating an oil-in-water mini-emulsion system consisting of $80 \%$ water, which led to yields of ca. $85 \%$ for the synthesis of hexyl octanoate (HxOc) after $24 \mathrm{~h}$ [163]. The same group, in order to make the process feasible, tried to increase the final product concentration by keeping the substrate concentration constant in a fed-batch mode for five days, yielding $1 \mathrm{M}$ of HxOc. Furthermore, the enzyme was reused in new $24 \mathrm{~h}$ reaction cycles $(\times 4)$, after separating the aqueous phase from the emulsion system, which led to a total product yield of 1.1 M. Sipponen at al., who used a novel immobilization/entrapment technique for $\mathrm{HiC}$, managed to increase the water:hexane ratio in their reaction system from 1 to 9 for the synthesis of butyl butyrate [88]. The enzyme retained $70 \%$ of its synthetic activity in the aqueous reaction system, leading to product yields of $52 \%$ after $24 \mathrm{~h}$. In addition, a biphasic system consisting of $80 \%$ water was utilized for the synthesis of tyrosyl fatty-acid esters by an F. oxysporum cutinase in its free form [164]. The oil phase was a vinyl ester, which was also the acyl donor for the reaction. Thermodynamic studies of the reaction system suggested that the enzyme acted in the aqueous phase, which was saturated with the vinyl ester, and that the majority of the produced tyrosyl ester was transferred into the oil phase, and was thus protected from potential hydrolysis. The equilibrium of tyrosyl butyrate synthesis reaction in $\mathrm{pH} 7$ was achieved after $4 \mathrm{~h}$ at $20^{\circ} \mathrm{C}$, and the conversion yield of tyrosol was ca. $61 \%$.

When it comes to polycondensation reactions, literature abounds with Novozym ${ }^{\circledR} 435$ (N435) references. N435 is the commercially available lipase B from C. antarctica immobilized on acrylic resin, which has been used for the synthesis of various polyesters, and even polyamides [165]. Cutinase-wise, $\mathrm{HiC}$ has been the most used for various polycondensation reactions. Its chain length specificity for the synthesis of polymers has been studied, and it has been shown that this cutinase prefers longer chain lengths than other cutinases. For instance, when used for the homopolymerization of $\omega$-hydroxyalkanoic acids, it showed specificity for the $C_{16}$ chain, while it could not polymerize chains shorter than 12 carbon atoms [166]. The HiC-produced poly(hydroxyhexadecanoate) had a molecular weight $\left(M_{\mathrm{n}}\right)$ of $40,400 \mathrm{~g} / \mathrm{mol}, 1.6$ times higher than the one produced by N435 (after $8 \mathrm{~h}$ at $70{ }^{\circ} \mathrm{C}$ ). The ability of cutinases from $A$. fumigatus and $F$. solani for $\omega$-hydroxy-hexadecanoic acid homopolymerization was also tested [104]. The products after $24 \mathrm{~h}$ reached $M_{\mathrm{n}}$ of approximately 25,000 g/mol for A. fumigatus cutinase (similar to N435), and $2300 \mathrm{~g} / \mathrm{mol}$ for FsC. Moreover, HiC has been used for ring-opening polycondensation reactions of lactones in bulk and toluene systems at $70{ }^{\circ} \mathrm{C}$. Toluene systems gave higher $M_{\mathrm{n}}$ for poly( $\varepsilon$-caprolactone) synthesis than bulk synthesis 
(24,900 and 16,000 g/mol, respectively) [167]. Other than $\varepsilon$-caprolactone, HiC can also polymerize $\omega$-pentadecalactone, showing similar $M_{n}$ with $\mathrm{N} 435$; however, it could not convert $\beta$-butyrolactone and L-lactide [168]. Finally, $\mathrm{HiC}$ has been used for the polycondensation of diacids and diols, with a preference for longer chain-lengths, namely $\mathrm{C}_{8}$ for diols, and $\mathrm{C}_{13}$ for diacids, leading to a product with $M_{\mathrm{n}}$ of $11,000 \mathrm{~g} / \mathrm{mol}$ after $8 \mathrm{~h}$ [166]. Also, the activity of $\mathrm{HiC}$ on cyclodiol 1,4-cyclohexanedimethanol has been studied with diacids of various chain-lengths $\left(C_{4}-C_{10}\right)$ [167]. The highest $M_{n}$ resulted from the $C_{10}$ diacid $(19,000 \mathrm{~g} / \mathrm{mol})$, while for the rest, $M_{n}$ was estimated to be lower than $5000 \mathrm{~g} / \mathrm{mol}$. Thc_cut1 from T. cellulosilytica was used for the reaction of dimethyl adipate with 1,4-butanediol (BDO) towards the formation of oligomers with an $M_{\mathrm{n}}$ of $985 \mathrm{~g} / \mathrm{mol}$ [169], while HiC could polymerize adipic acid and BDO with an $M_{n}$ of $2700 \mathrm{~g} / \mathrm{mol}$ [167]. Besides polyesters, cutinases have also been used for the synthesis of polyamides. FsC was able to synthesize oligomers of aliphatic diamines $\left(C_{4}-C_{8}\right)$ and $p$-xylylenediamine with diethyl sebacate $\left(\mathrm{C}_{10}\right)$, and also oligomers of 1,8-diaminooctane with dimethyl teraphthelate $[170,171]$.

Author Contributions: All authors contributed to the preparation of this paper.

Funding: This research received no external funding.

Conflicts of Interest: The authors declare no conflict of interest.

\section{References}

1. Fich, E.A.; Segerson, N.A.; Rose, J.K.C. The plant polyester cutin: Biosynthesis, structure, and biological roles. Annu. Rev. Plant Biol. 2016, 67, 207-233. [CrossRef] [PubMed]

2. Van Kan, J.A.L.; van't Klooster, J.W.; Wagemakers, C.A.M.; Dees, D.C.T.; van der Vlugt-Bergmans, C.J.B. Cutinase A of Botrytis cinerea is expressed, but not essential, during penetration of gerbera and tomato. Mol. Plant-Microbe Interact. 1997, 10, 30-38. [CrossRef] [PubMed]

3. Lu, L.; Rong, W.; Massart, S.; Zhang, Z. Genome-wide identification and expression analysis of cutinase gene family in Rhizoctonia cerealis and functional study of an active cutinase RcCUT1 in the fungal-wheat interaction. Front. Microbiol. 2018, 9, 1813. [CrossRef] [PubMed]

4. Wang, Y.; Chen, J.; Li, D.-W.; Zheng, L.; Huang, J. CglCUT1 gene required for cutinase activity and pathogenicity of Colletotrichum gloeosporioides causing anthracnose of Camellia oleifera. Eur. J. Plant Pathol. 2017, 147, 103-114. [CrossRef]

5. Li, D.; Ashby, A.M.; Johnstone, K. Molecular evidence that the extracellular cutinase $\mathrm{Pbc1}$ is required for pathogenicity of Pyrenopeziza brassicae on oilseed rape. Mol. Plant-Microbe Interact. 2003, 16, 545-552. [CrossRef] [PubMed]

6. Rogers, L.M.; Flaishman, M.A.; Kolattukudy, P.E. Cutinase gene disruption in Fusarium solani $f$ sp. pisi decreases its virulence on pea. Plant Cell 1994, 6, 935-945. [CrossRef] [PubMed]

7. Dickman, M.B.; Patil, S.S. Cutinase deficient mutants of Colletotrichum gloeosporioides are nonpathogenic to papaya fruit. Physiol. Mol. Plant Pathol. 1986, 28, 235-242. [CrossRef]

8. Dickman, M.B.; Podila, G.K.; Kolattukudy, P.E. Insertion of cutinase gene into a wound pathogen enables it to infect intact host. Nature 1989, 342, 446-448. [CrossRef]

9. Heinen, W. On the enzymatic degradation of cutin. IV. Separation of cutinase from associated oxidative enzymes. Enzymologia 1963, 25, 281-291.

10. Shishiyama, J.; Araki, F.; Akai, S. Studies on cutin-esterase II. Characteristics of cutin-esterase from Botrytis cinerea and its activity on tomato-cutin. Plant Cell Physiol. 1970, 11, 937-945. [CrossRef]

11. Kolattukudy, P.E. Biosynthesis of a lipid polymer, cutin: The structural component of plant cuticle. Biochem. Biophys. Res. Commun. 1970, 41, 299-305. [CrossRef]

12. Purdy, R.E.; Kolattukudy, P.E. Depolymerization of a hydroxy fatty acid biopolymer, cutin, by an extracellular enzyme from Fusarium solani f. pisi: Isolation and some properties of the enzyme. Arch. Biochem. Biophys. 1973, 159, 61-69. [CrossRef]

13. Purdy, R.E.; Kolattukudy, P.E. Hydrolysis of plant cuticle by plant pathogens. Properties of cutinase I, cutinase II, and a nonspecific esterase isolated from Fusarium solani pisi. Biochemistry 1975, 14, 2832-2840. [CrossRef] [PubMed] 
14. Carvalho, C.M.L.; Aires-Barros, M.R.; Cabral, J.M.S. Cutinase structure, function and biocatalytic applications. Electron. J. Biotechnol. 1998, 1, 160-173. [CrossRef]

15. Dutta, K.; Sen, S.; Veeranki, V.D. Production, characterization and applications of microbial cutinases. Process Biochem. 2009, 44, 127-134. [CrossRef]

16. Chen, S.; Su, L.; Chen, J.; Wu, J. Cutinase: Characteristics, preparation, and application. Biotechnol. Adv. 2013, 31, 1754-1767. [CrossRef]

17. Shinozaki, Y.; Morita, T.; Cao, X.; Yoshida, S.; Koitabashi, M.; Watanabe, T.; Suzuki, K.; Sameshima-Yamashita, Y.; Nakajima-Kambe, T.; Fujii, T.; et al. Biodegradable plastic-degrading enzyme from Pseudozyma antarctica: Cloning, sequencing, and characterization. Appl. Microbiol. Biotechnol. 2013, 97, 2951-2959. [CrossRef] [PubMed]

18. Roussel, A.; Amara, S.; Nyyssölä, A.; Mateos-Diaz, E.; Blangy, S.; Kontkanen, H.; Westerholm-Parvinen, A.; Carrière, F.; Cambillau, C. A cutinase from Trichoderma reesei with a lid-covered active site and kinetic properties of true lipases. J. Mol. Biol. 2014, 426, 3757-3772. [CrossRef] [PubMed]

19. Bischoff, F.; Litwińska, K.; Cordes, A.; Baronian, K.; Bode, R.; Schauer, F.; Kunze, G. Three new cutinases from the yeast Arxula adeninivorans that are suitable for biotechnological applications. Appl. Environ. Microbiol. 2015, 81, 5497-5510. [CrossRef]

20. Sebastião, M.J.; Cabral, J.M.S.; Aires-Barros, M.R. Improved purification protocol of a Fusarium solani pisi recombinant cutinase by phase partitioning in aqueous two-phase systems of polyethylene glycol and phosphate. Enzyme Microb. Technol. 1996, 18, 251-260. [CrossRef]

21. Dimarogona, M.; Nikolaivits, E.; Kanelli, M.; Christakopoulos, P.; Sandgren, M.; Topakas, E. Structural and functional studies of a Fusarium oxysporum cutinase with polyethylene terephthalate modification potential. Biochim. Biophys. Acta-Gen. Subj. 2015, 1850, 2308-2317. [CrossRef] [PubMed]

22. Nikolaivits, E.; Kokkinou, A.; Karpusas, M.; Topakas, E. Microbial host selection and periplasmic folding in Escherichia coli affect the biochemical characteristics of a cutinase from Fusarium oxysporum. Protein Expr. Purif. 2016, 127, 1-7. [CrossRef]

23. Thumarat, U.; Nakamura, R.; Kawabata, T.; Suzuki, H.; Kawai, F. Biochemical and genetic analysis of a cutinase-type polyesterase from a thermophilic Thermobifida alba AHK119. Appl. Microbiol. Biotechnol. 2012, 95, 419-430. [CrossRef] [PubMed]

24. Wei, R.; Oeser, T.; Then, J.; Kühn, N.; Barth, M.; Schmidt, J.; Zimmermann, W. Functional characterization and structural modeling of synthetic polyester-degrading hydrolases from Thermomonospora curvata. AMB Express 2014, 4, 44. [CrossRef]

25. Xu, H.; Yan, Q.; Duan, X.; Yang, S.; Jiang, Z. Characterization of an acidic cold-adapted cutinase from Thielavia terrestris and its application in flavor ester synthesis. Food Chem. 2015, 188, 439-445. [CrossRef]

26. Yang, S.; Xu, H.; Yan, Q.; Liu, Y.; Zhou, P.; Jiang, Z. A low molecular mass cutinase of Thielavia terrestris efficiently hydrolyzes poly(esters). J. Ind. Microbiol. Biotechnol. 2013, 40, 217-226. [CrossRef] [PubMed]

27. Suzuki, K.; Sakamoto, H.; Shinozaki, Y.; Tabata, J.; Watanabe, T.; Mochizuki, A.; Koitabashi, M.; Fujii, T.; Tsushima, S.; Kitamoto, H.K. Affinity purification and characterization of a biodegradable plastic-degrading enzyme from a yeast isolated from the larval midgut of a stag beetle, Aegus laevicollis. Appl. Microbiol. Biotechnol. 2013, 97, 7679-7688. [CrossRef] [PubMed]

28. Suzuki, K.; Noguchi, M.T.; Shinozaki, Y.; Koitabashi, M.; Sameshima-Yamashita, Y.; Yoshida, S.; Fujii, T.; Kitamoto, H.K. Purification, characterization, and cloning of the gene for a biodegradable plastic-degrading enzyme from Paraphoma-related fungal strain B47-9. Appl. Microbiol. Biotechnol. 2014, 98, 4457-4465. [CrossRef] [PubMed]

29. Maeda, H.; Yamagata, Y.; Abe, K.; Hasegawa, F.; Machida, M.; Ishioka, R.; Gomi, K.; Nakajima, T. Purification and characterization of a biodegradable plastic-degrading enzyme from Aspergillus oryzae. Appl. Microbiol. Biotechnol. 2005, 67, 778-788. [CrossRef]

30. Bermúdez-García, E.; Peña-Montes, C.; Castro-Rodríguez, J.A.; González-Canto, A.; Navarro-Ocaña, A.; Farrés, A. ANCUT2, a thermo-alkaline cutinase from Aspergillus nidulans and its potential applications. Appl. Biochem. Biotechnol. 2017, 182, 1014-1036. [CrossRef]

31. Wang, G.Y.; Michailides, T.J.; Hammock, B.D.; Lee, Y.-M.; Bostock, R.M. Molecular cloning, characterization, and expression of a redox-responsive cutinase from Monilinia fructicola (wint.) honey. Fungal Genet. Biol. 2002, 35, 261-276. [CrossRef] 
32. Thumarat, U.; Kawabata, T.; Nakajima, M.; Nakajima, H.; Sugiyama, A.; Yazaki, K.; Tada, T.; Waku, T.; Tanaka, N.; Kawai, F. Comparison of genetic structures and biochemical properties of tandem cutinase-type polyesterases from Thermobifida alba AHK119. J. Biosci. Bioeng. 2015, 120, 491-497. [CrossRef]

33. Nyyssölä, A.; Pihlajaniemi, V.; Järvinen, R.; Mikander, S.; Kontkanen, H.; Kruus, K.; Kallio, H.; Buchert, J. Screening of microbes for novel acidic cutinases and cloning and expression of an acidic cutinase from Aspergillus niger CBS 513.88. Enzyme Microb. Technol. 2013, 52, 272-278. [CrossRef]

34. Nyyssölä, A.; Pihlajaniemi, V.; Häkkinen, M.; Kontkanen, H.; Saloheimo, M.; Nakari-Setälä, T. Cloning and characterization of a novel acidic cutinase from Sirococcus conigenus. Appl. Microbiol. Biotechnol. 2014, 98, 3639-3650. [CrossRef]

35. Martinez, C.; De Geus, P.; Lauwereys, M.; Matthyssens, G.; Cambillau, C. Fusarium solani cutinase is a lipolytic enzyme with a catalytic serine accessible to solvent. Nature 1992, 356, 615-618. [CrossRef]

36. Longhi, S.; Cambillau, C. Structure-activity of cutinase, a small lipolytic enzyme. Biochim. Biophys. Acta-Mol. Cell Biol. Lipids 1999, 1441, 185-196. [CrossRef]

37. Longhi, S.; Czjzek, M.; Lamzin, V.; Nicolas, A.; Cambillau, C. Atomic resolution (1.0 A) crystal structure of Fusarium solani cutinase: Stereochemical analysis. J. Mol. Biol. 1997, 268, 779-799. [CrossRef]

38. Roth, C.; Wei, R.; Oeser, T.; Then, J.; Föllner, C.; Zimmermann, W.; Sträter, N. Structural and functional studies on a thermostable polyethylene terephthalate degrading hydrolase from Thermobifida fusca. Appl. Microbiol. Biotechnol. 2014, 98, 7815-7823. [CrossRef]

39. Han, X.; Liu, W.; Huang, J.-W.W.; Ma, J.; Zheng, Y.; Ko, T.-P.P.; Xu, L.; Cheng, Y.-S.S.; Chen, C.-C.C.; Guo, R.-T.T. Structural insight into catalytic mechanism of PET hydrolase. Nat. Commun. 2017, 8, 2106. [CrossRef]

40. Chen, S.; Tong, X.; Woodard, R.W.; Du, G.; Wu, J.; Chen, J. Identification and characterization of bacterial cutinase. J. Biol. Chem. 2008, 283, 25854-25862. [CrossRef]

41. Herrero Acero, E.; Ribitsch, D.; Steinkellner, G.; Gruber, K.; Greimel, K.; Eiteljoerg, I.; Trotscha, E.; Wei, R.; Zimmermann, W.; Zinn, M.; et al. Enzymatic surface hydrolysis of PET: Effect of structural diversity on kinetic properties of cutinases from Thermobifida. Macromolecules 2011, 44, 4632-4640. [CrossRef]

42. Ribitsch, D.; Acero, E.H.; Greimel, K.; Eiteljoerg, I.; Trotscha, E.; Freddi, G.; Schwab, H.; Guebitz, G.M. Characterization of a new cutinase from Thermobifida alba for PET-surface hydrolysis. Biocatal. Biotransform. 2012, 30, 2-9. [CrossRef]

43. Hegde, K.; Veeranki, V.D. Production optimization and characterization of recombinant cutinases from Thermobifida fusca sp. NRRL B-8184. Appl. Biochem. Biotechnol. 2013, 170, 654-675. [CrossRef]

44. Sulaiman, S.; Yamato, S.; Kanaya, E.; Kim, J.-J.; Koga, Y.; Takano, K.; Kanaya, S. Isolation of a novel cutinase homolog with polyethylene terephthalate-degrading activity from leaf-branch compost by using a metagenomic approach. Appl. Environ. Microbiol. 2012, 78, 1556-1562. [CrossRef]

45. Kwon, M.-A.; Kim, H.S.; Yang, T.H.; Song, B.K.; Song, J.K. High-level expression and characterization of Fusarium solani cutinase in Pichia pastoris. Protein Expr. Purif. 2009, 68, 104-109. [CrossRef]

46. Rubio, M.B.; Cardoza, R.E.; Hermosa, R.; Gutiérrez, S.; Monte, E. Cloning and characterization of the Thcut1 gene encoding a cutinase of Trichoderma harzianum T34. Curr. Genet. 2008, 54, 301-312. [CrossRef]

47. Liu, Z.; Gosser, Y.; Baker, P.J.; Ravee, Y.; Lu, Z.; Alemu, G.; Li, H.; Butterfoss, G.L.; Kong, X.-P.; Gross, R.; et al. Structural and functional studies of Aspergillus oryzae cutinase: Enhanced thermostability and hydrolytic activity of synthetic ester and polyester degradation. J. Am. Chem. Soc. 2009, 131, 15711-15716. [CrossRef]

48. Koschorreck, K.; Liu, D.; Kazenwadel, C.; Schmid, R.D.; Hauer, B. Heterologous expression, characterization and site-directed mutagenesis of cutinase CUTAB1 from Alternaria brassicicola. Appl. Microbiol. Biotechnol. 2010, 87, 991-997. [CrossRef]

49. Kazenwadel, C.; Eiben, S.; Maurer, S.; Beuttler, H.; Wetzl, D.; Hauer, B.; Koschorreck, K. Thiolfunctionalization of acrylic ester monomers catalyzed by immobilized Humicola insolens cutinase. Enzyme Microb. Technol. 2012, 51, 9-15. [CrossRef]

50. Seman, W.M.K.W.; Bakar, S.A.; Bukhari, N.A.; Gaspar, S.M.; Othman, R.; Nathan, S.; Mahadi, N.M.; Jahim, J.; Murad, A.M.A.; Bakar, F.D.A. High level expression of Glomerella cingulata cutinase in dense cultures of Pichia pastoris grown under fed-batch conditions. J. Biotechnol. 2014, 184, 219-228. [CrossRef]

51. Duan, X.; Liu, Y.; You, X.; Jiang, Z.; Yang, S.; Yang, S. High-level expression and characterization of a novel cutinase from Malbranchea cinnamomea suitable for butyl butyrate production. Biotechnol. Biofuels 2017, 10, 223. [CrossRef] 
52. Yang, S.; Liu, M.; Long, L.; Zhang, R.; Ding, S. Characterization of a cutinase from Myceliophthora thermophila and its application in polyester hydrolysis and deinking process. Process Biochem. 2018, 66, $106-112$. [CrossRef]

53. Kodama, Y.; Masaki, K.; Kondo, H.; Suzuki, M.; Tsuda, S.; Nagura, T.; Shimba, N.; Suzuki, E.; Iefuji, H. Crystal structure and enhanced activity of a cutinase-like enzyme from Cryptococcus sp. strain S-2. Proteins Struct. Funct. Bioinform. 2009, 77, 710-717. [CrossRef]

54. Nyon, M.P.; Rice, D.W.; Berrisford, J.M.; Huang, H.; Moir, A.J.G.; Craven, C.J.; Nathan, S.; Mahadi, N.M.; Abu Bakar, F.D. Crystallization and preliminary X-ray analysis of recombinant Glomerella cingulata cutinase. Acta Crystallogr. Sect. F Struct. Biol. Cryst. Commun. 2008, 64, 504-508. [CrossRef]

55. Kold, D.; Dauter, Z.; Laustsen, A.K.; Brzozowski, A.M.; Turkenburg, J.P.; Nielsen, A.D.; Koldsø, H.; Petersen, E.; Schiøtt, B.; De Maria, L.; et al. Thermodynamic and structural investigation of the specific SDS binding of Humicola insolens cutinase. Protein Sci. 2014, 23, 1023-1035. [CrossRef]

56. Kitadokoro, K.; Thumarat, U.; Nakamura, R.; Nishimura, K.; Karatani, H.; Suzuki, H.; Kawai, F. Crystal structure of cutinase Est119 from Thermobifida alba AHK119 that can degrade modified polyethylene terephthalate at $1.76 \AA$ A resolution. Polym. Degrad. Stab. 2012, 97, 771-775. [CrossRef]

57. Sulaiman, S.; You, D.-J.; Kanaya, E.; Koga, Y.; Kanaya, S. Crystal structure and thermodynamic and kinetic stability of metagenome-derived LC-cutinase. Biochemistry 2014, 53, 1858-1869. [CrossRef]

58. Miyakawa, T.; Mizushima, H.; Ohtsuka, J.; Oda, M.; Kawai, F.; Tanokura, M. Structural basis for the $\mathrm{Ca}^{2+}$-enhanced thermostability and activity of PET-degrading cutinase-like enzyme from Saccharomonospora viridis AHK190. Appl. Microbiol. Biotechnol. 2015, 99, 4297-4307. [CrossRef]

59. Ribitsch, D.; Hromic, A.; Zitzenbacher, S.; Zartl, B.; Gamerith, C.; Pellis, A.; Jungbauer, A.; Łyskowski, A.; Steinkellner, G.; Gruber, K.; et al. Small cause, large effect: Structural characterization of cutinases from Thermobifida cellulosilytica. Biotechnol. Bioeng. 2017, 114, 2481-2488. [CrossRef]

60. Hegde, K.; Dasu, V.V. Structural stability and unfolding properties of cutinases from Thermobifida fusca. Appl. Biochem. Biotechnol. 2014, 174, 803-819. [CrossRef]

61. Shirke, A.N.; Basore, D.; Butterfoss, G.L.; Bonneau, R.; Bystroff, C.; Gross, R.A. Toward rational thermostabilization of Aspergillus oryzae cutinase: Insights into catalytic and structural stability. Proteins Struct. Funct. Bioinform. 2016, 84, 60-72. [CrossRef]

62. Numoto, N.; Kamiya, N.; Bekker, G.-J.; Yamagami, Y.; Inaba, S.; Ishii, K.; Uchiyama, S.; Kawai, F.; Ito, N.; Oda, M. Structural dynamics of the PET-degrading cutinase-like enzyme from Saccharomonospora viridis AHK190 in substrate-bound states elucidates the $\mathrm{Ca}^{2+}$-driven catalytic cycle. Biochemistry 2018. [CrossRef]

63. Herrero Acero, E.; Ribitsch, D.; Dellacher, A.; Zitzenbacher, S.; Marold, A.; Steinkellner, G.; Gruber, K.; Schwab, H.; Guebitz, G.M. Surface engineering of a cutinase from Thermobifida cellulosilytica for improved polyester hydrolysis. Biotechnol. Bioeng. 2013, 110, 2581-2590. [CrossRef]

64. Yoshida, S.; Hiraga, K.; Takehana, T.; Taniguchi, I.; Yamaji, H.; Maeda, Y.; Toyohara, K.; Miyamoto, K.; Kimura, Y.; Oda, K. A bacterium that degrades and assimilates poly(ethylene terephthalate). Science 2016, 351, 1196-1199. [CrossRef]

65. Joo, S.; Cho, I.J.; Seo, H.; Son, H.F.; Sagong, H.-Y.; Shin, T.J.; Choi, S.Y.; Lee, S.Y.; Kim, K.-J. Structural insight into molecular mechanism of poly(ethylene terephthalate) degradation. Nat. Commun. 2018, 9, 382. [CrossRef]

66. Fecker, T.; Galaz-Davison, P.; Engelberger, F.; Narui, Y.; Sotomayor, M.; Parra, L.P.; Ramírez-Sarmiento, C.A. Active site flexibility as a hallmark for efficient PET degradation by I. sakaiensis PETase. Biophys. J. 2018, 114, 1302-1312. [CrossRef]

67. Austin, H.P.; Allen, M.D.; Donohoe, B.S.; Rorrer, N.A.; Kearns, F.L.; Silveira, R.L.; Pollard, B.C.; Dominick, G.; Duman, R.; El Omari, K.; et al. Characterization and engineering of a plastic-degrading aromatic polyesterase. Proc. Natl. Acad. Sci. USA 2018, 115, E4350-E4357. [CrossRef]

68. Chen, C.-C.; Han, X.; Ko, T.-P.; Liu, W.; Guo, R.-T. Structural studies reveal the molecular mechanism of PETase. FEBS J. 2018, 285, 3717-3723. [CrossRef]

69. Haki, G.D.; Rakshit, S.K. Developments in industrially important thermostable enzymes: A review. Bioresour. Technol. 2003, 89, 17-34. [CrossRef]

70. Doukyu, N.; Ogino, H. Organic solvent-tolerant enzymes. Biochem. Eng. J. 2010, 48, 270-282. [CrossRef]

71. Chin, I.-S.; Murad, A.M.A.; Mahadi, N.M.; Nathan, S.; Bakar, F.D.A. Thermal stability engineering of Glomerella cingulata cutinase. Protein Eng. Des. Sel. 2013, 26, 369-375. [CrossRef] 
72. Shirke, A.N.; Basore, D.; Holton, S.; Su, A.; Baugh, E.; Butterfoss, G.L.; Makhatadze, G.; Bystroff, C.; Gross, R.A. Influence of surface charge, binding site residues and glycosylation on Thielavia terrestris cutinase biochemical characteristics. Appl. Microbiol. Biotechnol. 2016, 100, 4435-4446. [CrossRef] [PubMed]

73. Shirke, A.N.; White, C.; Englaender, J.A.; Zwarycz, A.; Butterfoss, G.L.; Linhardt, R.J.; Gross, R.A. Stabilizing leaf and branch compost cutinase (LCC) with glycosylation: Mechanism and effect on PET hydrolysis. Biochemistry 2018, 57, 1190-1200. [CrossRef] [PubMed]

74. Shirke, A.N.; Su, A.; Jones, J.A.; Butterfoss, G.L.; Koffas, M.A.G.; Kim, J.R.; Gross, R.A. Comparative thermal inactivation analysis of Aspergillus oryzae and Thiellavia terrestris cutinase: Role of glycosylation. Biotechnol. Bioeng. 2017, 114, 63-73. [CrossRef] [PubMed]

75. Hanapi, W.N.W.; Iuan-Sheau, C.; Mahadi, N.M.; Murad, A.M.A.; Bakar, F.D.A. Site-saturation mutagenesis of Glomerella cingulata cutinase gene for enhanced enzyme thermostability. In AIP Conference Proceedings; AIP Publishing LLC: Melville, NY, USA, 2015; Volume 1678, p. 030021.

76. Then, J.; Wei, R.; Oeser, T.; Barth, M.; Belisário-Ferrari, M.R.; Schmidt, J.; Zimmermann, W. Ca ${ }^{2+}$ and $\mathrm{Mg}^{2+}$ binding site engineering increases the degradation of polyethylene terephthalate films by polyester hydrolases from Thermobifida fusca. Biotechnol. J. 2015, 10, 592-598. [CrossRef] [PubMed]

77. Yamaguchi, H.; Kiyota, Y.; Miyazaki, M. Techniques for peparation of cross-linked enzyme aggregates and their applications in bioconversions. Catalysts 2018, 8, 174. [CrossRef]

78. Rodrigues, R.C.; Ortiz, C.; Berenguer-Murcia, Á.; Torres, R.; Fernández-Lafuente, R. Modifying enzyme activity and selectivity by immobilization. Chem. Soc. Rev. 2013, 42, 6290-6307. [CrossRef]

79. Silva, C.; Martins, M.; Jing, S.; Fu, J.; Cavaco-Paulo, A. Practical insights on enzyme stabilization. Crit. Rev. Biotechnol. 2018, 38, 335-350. [CrossRef]

80. Sousa, I.T.; Lourenço, N.M.T.; Afonso, C.A.M.; Taipa, M.A. Protein stabilization with a dipeptide-mimic triazine-scaffolded synthetic affinity ligand. J. Mol. Recognit. 2013, 26, 104-112. [CrossRef]

81. Zhang, C.; Zeng, G.; Huang, D.; Lai, C.; Huang, C.; Li, N.; Xu, P.; Cheng, M.; Zhou, Y.; Tang, W.; et al. Combined removal of di(2-ethylhexyl)phthalate (DEHP) and $\mathrm{Pb}$ ( ii ) by using a cutinase loaded nanoporous gold-polyethyleneimine adsorbent. RSC Adv. 2014, 4, 55511-55518. [CrossRef]

82. Su, A.; Shirke, A.; Baik, J.; Zou, Y.; Gross, R. Immobilized cutinases: Preparation, solvent tolerance and thermal stability. Enzyme Microb. Technol. 2018, 116, 33-40. [CrossRef] [PubMed]

83. Kumari, V.; Kumar, S.; Kaur, I.; Bhalla, T.C. Graft copolymerization of acrylamide on chitosan-co-chitin and its application for immobilization of Aspergillus sp. RL2Ct cutinase. Bioorg. Chem. 2017, 70, 34-43. [CrossRef] [PubMed]

84. Pellis, A.; Vastano, M.; Quartinello, F.; Herrero Acero, E.; Guebitz, G.M. His-tag immobilization of cutinase 1 from Thermobifida cellulosilytica for solvent-free synthesis of polyesters. Biotechnol. J. 2017, 12, 1700322. [CrossRef] [PubMed]

85. Muley, A.B.; Chaudhari, S.A.; Singhal, R.S. Non-covalent conjugation of cutinase from Fusarium sp. ICT SAC1 with pectin for enhanced stability: Process minutiae, kinetics, thermodynamics and structural study. Int. J. Biol. Macromol. 2017, 102, 729-740. [CrossRef]

86. Muley, A.B.; Chaudhari, S.A.; Mulchandani, K.H.; Singhal, R.S. Extraction and characterization of chitosan from prawn shell waste and its conjugation with cutinase for enhanced thermo-stability. Int. J. Biol. Macromol. 2018, 111, 1047-1058. [CrossRef]

87. Hegde, K.; Veeranki, V. Studies on immobilization of cutinases from Thermobifida fusca on glutaraldehyde activated chitosan beads. Br. Biotechnol. J. 2014, 4, 1049-1063. [CrossRef]

88. Sipponen, M.H.; Farooq, M.; Koivisto, J.; Pellis, A.; Seitsonen, J.; Österberg, M. Spatially confined lignin nanospheres for biocatalytic ester synthesis in aqueous media. Nat. Commun. 2018, 9, 2300. [CrossRef]

89. Chaudhari, S.A.; Singhal, R.S. A strategic approach for direct recovery and stabilization of Fusarium sp. ICT SAC1 cutinase from solid state fermented broth by carrier free cross-linked enzyme aggregates. Int. J. Biol. Macromol. 2017, 98, 610-621. [CrossRef]

90. Nikolaivits, E.; Makris, G.; Topakas, E. Immobilization of a cutinase from Fusarium oxysporum and application in pineapple flavor synthesis. J. Agric. Food Chem. 2017, 65, 3505-3511. [CrossRef]

91. Koshti, R.; Mehta, L.; Samarth, N. Biological recycling of polyethylene terephthalate: A mini-review. J. Polym. Environ. 2018, 26, 3520-3529. [CrossRef] 
92. Katiyar, V.; Gaur, S.S.; Pal, A.K.; Kumar, A. Properties of plastics for packaging applications. In Polymers for Packaging Applications; Alavi, S., Thomas, S., Sandeep, K.P., Kalarikkal, N., Varghese, J., Yaragalla, S., Eds.; Apple Academic Press, Inc.: Palm Bay, FL, USA, 2015; pp. 3-38.

93. Lyu, M.-Y.; Choi, T.G. Research trends in polymer materials for use in lightweight vehicles. Int. J. Precis. Eng. Manuf. 2015, 16, 213-220. [CrossRef]

94. Hirschler, M.M. Flame retardants and heat release: Review of data on individual polymers. Fire Mater. 2015, 39, 232-258. [CrossRef]

95. Vecchiato, S.; Ahrens, J.; Pellis, A.; Scaini, D.; Mueller, B.; Herrero Acero, E.; Guebitz, G.M. Enzymatic functionalization of HMLS-polyethylene terephthalate fabrics improves the adhesion to rubber. ACS Sustain. Chem. Eng. 2017, 5, 6456-6465. [CrossRef]

96. Geyer, R.; Jambeck, J.R.; Law, K.L. Production, use, and fate of all plastics ever made. Sci. Adv. 2017, 3, e1700782. [CrossRef] [PubMed]

97. Awaja, F.; Pavel, D. Recycling of PET. Eur. Polym. J. 2005, 41, 1453-1477. [CrossRef]

98. Ferrario, V.; Pellis, A.; Cespugli, M.; Guebitz, G.; Gardossi, L.; Ferrario, V.; Pellis, A.; Cespugli, M.; Guebitz, G.M.; Gardossi, L. Nature inspired solutions for polymers: Will cutinase enzymes make polyesters and polyamides greener? Catalysts 2016, 6, 205. [CrossRef]

99. Pan, W.; Bai, Z.; Su, T.; Wang, Z. Enzymatic degradation of poly(butylene succinate) with different molecular weights by cutinase. Int. J. Biol. Macromol. 2018, 111, 1040-1046. [CrossRef]

100. Hu, X.; Su, T.; Pan, W.; Li, P.; Wang, Z. Difference in solid-state properties and enzymatic degradation of three kinds of poly(butylene succinate)/cellulose blends. RSC Adv. 2017, 7, 35496-35503. [CrossRef]

101. Bai, Z.; Liu, Y.; Su, T.; Wang, Z.; Bai, Z.; Liu, Y.; Su, T.; Wang, Z. Effect of hydroxyl monomers on the enzymatic degradation of poly(ethylene succinate), poly(butylene succinate), and poly(hexylene succinate). Polymers (Basel) 2018, 10, 90. [CrossRef]

102. Watanabe, T.; Shinozaki, Y.; Yoshida, S.; Koitabashi, M.; Sameshima-Yamashita, Y.; Fujii, T.; Fukuoka, T.; Kitamoto, H.K. Xylose induces the phyllosphere yeast Pseudozyma antarctica to produce a cutinase-like enzyme which efficiently degrades biodegradable plastics. J. Biosci. Bioeng. 2014, 117, 325-329. [CrossRef]

103. Abdel-Motaal, F.F.; El-Sayed, M.A.; El-Zayat, S.A.; Ito, S. Biodegradation of poly ( $\varepsilon$-caprolactone) (PCL) film and foam plastic by Pseudozyma japonica sp. nov., a novel cutinolytic ustilaginomycetous yeast species. 3 Biotech 2014, 4, 507-512. [CrossRef] [PubMed]

104. Ping, L.-F.; Chen, X.-Y.; Yuan, X.-L.; Zhang, M.; Chai, Y.-J.; Shan, S.-D. Application and comparison in biosynthesis and biodegradation by Fusarium solani and Aspergillus fumigatus cutinases. Int. J. Biol. Macromol. 2017, 104, 1238-1245. [CrossRef] [PubMed]

105. Adıgüzel, A.O.; Tunçer, M. Purification and characterization of cutinase from Bacillus sp. KY0701 isolated from plastic wastes. Prep. Biochem. Biotechnol. 2017, 47, 925-933. [CrossRef] [PubMed]

106. Gamerith, C.; Zartl, B.; Pellis, A.; Guillamot, F.; Marty, A.; Acero, E.H.; Guebitz, G.M. Enzymatic recovery of polyester building blocks from polymer blends. Process Biochem. 2017, 59, 58-64. [CrossRef]

107. Pellis, A.; Gamerith, C.; Ghazaryan, G.; Ortner, A.; Herrero Acero, E.; Guebitz, G.M. Ultrasound-enhanced enzymatic hydrolysis of poly(ethylene terephthalate). Bioresour. Technol. 2016, 218, 1298-1302. [CrossRef] [PubMed]

108. Alves, N.M.; Mano, J.F.; Balaguer, E.; Meseguer Dueñas, J.M.; Gómez Ribelles, J.L. Glass transition and structural relaxation in semi-crystalline poly(ethylene terephthalate): A DSC study. Polymer (Guildf) 2002, 43, 4111-4122. [CrossRef]

109. Barth, M.; Oeser, T.; Wei, R.; Then, J.; Schmidt, J.; Zimmermann, W. Effect of hydrolysis products on the enzymatic degradation of polyethylene terephthalate nanoparticles by a polyester hydrolase from Thermobifida fusca. Biochem. Eng. J. 2015, 93, 222-228. [CrossRef]

110. Castro, A.M.D.; Carniel, A. A novel process for poly(ethylene terephthalate) depolymerization via enzyme-catalyzed glycolysis. Biochem. Eng. J. 2017, 124, 64-68. [CrossRef]

111. Castro, A.M.D.; Carniel, A.; Sirelli, L.; Dias, M.L.; Menezes, S.M.C.D.; Chinelatto Junior, L.S.; Honorato, H.D.A. Enzyme-catalyzed simultaneous hydrolysis-glycolysis reactions reveals tunability on PET depolymerization products. Biochem. Eng. J. 2018, 137, 239-246. [CrossRef]

112. Weinberger, S.; Canadell, J.; Quartinello, F.; Yeniad, B.; Arias, A.; Pellis, A.; Guebitz, G.; Weinberger, S.; Canadell, J.; Quartinello, F.; et al. Enzymatic degradation of poly(ethylene 2,5-furanoate) powders and amorphous films. Catalysts 2017, 7, 318. [CrossRef] 
113. Weinberger, S.; Haernvall, K.; Scaini, D.; Ghazaryan, G.; Zumstein, M.T.; Sander, M.; Pellis, A.; Guebitz, G.M. Enzymatic surface hydrolysis of poly(ethylene furanoate) thin films of various crystallinities. Green Chem. 2017, 19, 5381-5384. [CrossRef]

114. Schmidt, J.; Wei, R.; Oeser, T.; Dedavid e Silva, L.; Breite, D.; Schulze, A.; Zimmermann, W.; Schmidt, J.; Wei, R.; Oeser, T.; et al. Degradation of polyester polyurethane by bacterial polyester hydrolases. Polymers (Basel) 2017, 9, 65. [CrossRef]

115. Hou, S.; Hoyle, D.M.; Blackwell, C.J.; Haernvall, K.; Perz, V.; Guebitz, G.M.; Khosravi, E. Hydrolytic degradation of ROMP thermosetting materials catalysed by bio-derived acids and enzymes: From networks to linear materials. Green Chem. 2016, 18, 5190-5199. [CrossRef]

116. Haernvall, K.; Zitzenbacher, S.; Biundo, A.; Yamamoto, M.; Schick, M.B.; Ribitsch, D.; Guebitz, G.M. Enzymes as enhancers for the biodegradation of synthetic polymers in wastewater. ChemBioChem 2018, 19, 317-325. [CrossRef] [PubMed]

117. Whiteford, J.R.; Spanu, P.D. Hydrophobins and the interactions between fungi and plants. Mol. Plant Pathol. 2002, 3, 391-400. [CrossRef] [PubMed]

118. Ribitsch, D.; Herrero Acero, E.; Przylucka, A.; Zitzenbacher, S.; Marold, A.; Gamerith, C.; Tscheließnig, R.; Jungbauer, A.; Rennhofer, H.; Lichtenegger, H.; et al. Enhanced cutinase-catalyzed hydrolysis of polyethylene terephthalate by covalent fusion to hydrophobins. Appl. Environ. Microbiol. 2015, 81, 3586-3592. [CrossRef] [PubMed]

119. Terauchi, Y.; Kim, Y.-K.; Tanaka, T.; Nanatani, K.; Takahashi, T.; Abe, K. Asp30 of Aspergillus oryzae cutinase CutL1 is involved in the ionic interaction with fungal hydrophobin RolA. Biosci. Biotechnol. Biochem. 2017, 81, 1363-1368. [CrossRef]

120. Takahashi, T.; Tanaka, T.; Tsushima, Y.; Muragaki, K.; Uehara, K.; Takeuchi, S.; Maeda, H.; Yamagata, Y.; Nakayama, M.; Yoshimi, A.; et al. Ionic interaction of positive amino acid residues of fungal hydrophobin RolA with acidic amino acid residues of cutinase CutL1. Mol. Microbiol. 2015, 96, 14-27. [CrossRef]

121. Tanaka, T.; Nakayama, M.; Takahashi, T.; Nanatani, K.; Yamagata, Y.; Abe, K. Analysis of the ionic interaction between the hydrophobin RodA and two cutinases of Aspergillus nidulans obtained via an Aspergillus oryzae expression system. Appl. Microbiol. Biotechnol. 2017, 101, 2343-2356. [CrossRef]

122. Ribitsch, D.; Yebra, A.O.; Zitzenbacher, S.; Wu, J.; Nowitsch, S.; Steinkellner, G.; Greimel, K.; Doliska, A.; Oberdorfer, G.; Gruber, C.C.; et al. Fusion of binding domains to Thermobifida cellulosilytica cutinase to tune sorption characteristics and enhancing PET hydrolysis. Biomacromolecules 2013, 14, 1769-1776. [CrossRef]

123. Wei, R.; Oeser, T.; Schmidt, J.; Meier, R.; Barth, M.; Then, J.; Zimmermann, W. Engineered bacterial polyester hydrolases efficiently degrade polyethylene terephthalate due to relieved product inhibition. Biotechnol. Bioeng. 2016, 113, 1658-1665. [CrossRef] [PubMed]

124. Kawai, F.; Oda, M.; Tamashiro, T.; Waku, T.; Tanaka, N.; Yamamoto, M.; Mizushima, H.; Miyakawa, T.; Tanokura, M. A novel $\mathrm{Ca}^{2+}$-activated, thermostabilized polyesterase capable of hydrolyzing polyethylene terephthalate from Saccharomonospora viridis AHK190. Appl. Microbiol. Biotechnol. 2014, 98, 10053-10064. [CrossRef] [PubMed]

125. Zhang, Y.; Wang, L.; Chen, J.; Wu, J. Enhanced activity toward PET by site-directed mutagenesis of Thermobifida fusca cutinase-CBM fusion protein. Carbohydr. Polym. 2013, 97, 124-129. [CrossRef] [PubMed]

126. Liu, B.; He, L.; Wang, L.; Li, T.; Li, C.; Liu, H.; Luo, Y.; Bao, R. Protein crystallography and site-direct mutagenesis analysis of the poly(ethylene terephthalate) hydrolase PETase from Ideonella sakaiensis. ChemBioChem 2018, 19, 1471-1475. [CrossRef] [PubMed]

127. Hu, X.; Gao, Z.; Wang, Z.; Su, T.; Yang, L.; Li, P. Enzymatic degradation of poly(butylene succinate) by cutinase cloned from Fusarium solani. Polym. Degrad. Stab. 2016, 134, 211-219. [CrossRef]

128. Groß, C.; Hamacher, K.; Schmitz, K.; Jager, S. Cleavage product accumulation decreases the activity of cutinase during PET hydrolysis. J. Chem. Inf. Model. 2017, 57, 243-255. [CrossRef] [PubMed]

129. Carniel, A.; Valoni, É.; Nicomedes, J.; Gomes, A.D.C.; Castro, A.M. de Lipase from Candida antarctica (CALB) and cutinase from Humicola insolens act synergistically for PET hydrolysis to terephthalic acid. Process Biochem. 2017, 59, 84-90. [CrossRef]

130. De Castro, A.M.; Carniel, A.; Nicomedes Junior, J.; da Conceição Gomes, A.; Valoni, É. Screening of commercial enzymes for poly(ethylene terephthalate) (PET) hydrolysis and synergy studies on different substrate sources. J. Ind. Microbiol. Biotechnol. 2017, 44, 835-844. [CrossRef] 
131. Barth, M.; Honak, A.; Oeser, T.; Wei, R.; Belisário-Ferrari, M.R.; Then, J.; Schmidt, J.; Zimmermann, W. A dual enzyme system composed of a polyester hydrolase and a carboxylesterase enhances the biocatalytic degradation of polyethylene terephthalate films. Biotechnol. J. 2016, 11, 1082-1087. [CrossRef]

132. Schmidt, J.; Wei, R.; Oeser, T.; Belisário-Ferrari, M.R.; Barth, M.; Then, J.; Zimmermann, W. Effect of Tris, MOPS, and phosphate buffers on the hydrolysis of polyethylene terephthalate films by polyester hydrolases. FEBS Open Bio 2016, 6, 919-927. [CrossRef]

133. Saxena, A.; Singh Chauhan, P. Role of various enzymes for deinking paper: A review. Crit. Rev. Biotechnol. 2017, 37, 598-612. [CrossRef] [PubMed]

134. Wang, F.; Zhang, X.; Zhang, G.; Chen, J.; Sang, M.; Long, Z.; Wang, B. Studies on the environmentally friendly deinking process employing biological enzymes and composite surfactant. Cellulose 2018, 25, 3079-3089. [CrossRef]

135. Hong, R.; Su, L.; Chen, S.; Long, Z.; Wu, J. Comparison of cutinases in enzymic deinking of old newsprint. Cellulose 2017, 24, 5089-5099. [CrossRef]

136. Liu, M.; Yang, S.; Long, L.; Cao, Y.; Ding, S. Engineering a chimeric lipase-cutinase (Lip-Cut) for efficient enzymatic deinking of waste paper. BioResources 2017, 13, 981-996. [CrossRef]

137. Hong, R.; Su, L.; Wu, J. Cutinases catalyze polyacrylate hydrolysis and prevent their aggregation. Polym. Degrad. Stab. 2019, 159, 23-30. [CrossRef]

138. Gao, D.-W.; Wen, Z.-D. Phthalate esters in the environment: A critical review of their occurrence, biodegradation, and removal during wastewater treatment processes. Sci. Total Environ. 2016, 541, 986-1001. [CrossRef] [PubMed]

139. Kim, Y.-H.; Min, J.; Bae, K.-D.; Gu, M.B.; Lee, J. Biodegradation of dipropyl phthalate and toxicity of its degradation products: A comparison of Fusarium oxysporum f. sp. pisi cutinase and Candida cylindracea esterase. Arch. Microbiol. 2005, 184, 25-31. [CrossRef] [PubMed]

140. Kim, Y.-H.; Lee, J. Enzymatic degradation of dibutyl phthalate and toxicity of its degradation products. Biotechnol. Lett. 2005, 27, 635-639. [CrossRef]

141. Ahn, J.-Y.; Kim, Y.-H.; Min, J.; Lee, J. Accelerated degradation of dipentyl phthalate by Fusarium oxysporum f. sp. pisi cutinase and toxicity evaluation of its degradation products using bioluminescent bacteria. Curr. Microbiol. 2006, 52, 340-344. [CrossRef]

142. Kim, Y.-H.; Seo, H.-S.; Min, J.; Kim, Y.-C.; Ban, Y.-H.; Han, K.Y.; Park, J.-S.; Bae, K.-D.; Gu, M.B.; Lee, J. Enhanced degradation and toxicity reduction of dihexyl phthalate by Fusarium oxysporum $\mathrm{f}$. sp. pisi cutinase. J. Appl. Microbiol. 2007, 102, 221-228. [CrossRef]

143. Kim, Y.-H.; Lee, J.; Ahn, J.-Y.; Gu, M.B.; Moon, S.-H. Enhanced degradation of an endocrine-disrupting chemical, butyl benzyl phthalate, by Fusarium oxysporum f. sp. pisi cutinase. Appl. Environ. Microbiol. 2002, 68, 4684-4688. [CrossRef]

144. Kim, Y.-H.; Lee, J.; Moon, S.-H. Degradation of an endocrine disrupting chemical, DEHP [di-(2-ethylhexyl)-phthalate], by Fusarium oxysporum f. sp. pisi cutinase. Appl. Microbiol. Biotechnol. 2003, 63, 75-80. [CrossRef]

145. Viksoe-Nielsen, A.; Hauerbach Soerensen, B. Cutinase for Detoxification of Feed Products 2008, WO/2009/080701. 20 July 2009.

146. Viskoe-Nielsen, A.; Hauerbach Soerensen, B. Detoxification of Feed Products 2009, WO/2009/109607, 11 September 2009.

147. Kim, Y.-H.; Ahn, J.-Y.; Moon, S.-H.; Lee, J. Biodegradation and detoxification of organophosphate insecticide, malathion by Fusarium oxysporum $\mathrm{f}$. sp. pisi cutinase. Chemosphere 2005, 60, 1349-1355. [CrossRef] [PubMed]

148. Kawai, F.; Kawase, T.; Shiono, T.; Urakawa, H.; Sukigara, S.; Tu, C.; Yamamoto, M. Enzymatic hydrophilization of polyester fabrics using a recombinant cutinase Cut 190 and their surface characterization. J. Fiber Sci. Technol. 2017, 73, 8-18. [CrossRef]

149. Kanelli, M.; Vasilakos, S.; Nikolaivits, E.; Ladas, S.; Christakopoulos, P.; Topakas, E. Surface modification of poly(ethylene terephthalate) (PET) fibers by a cutinase from Fusarium oxysporum. Process Biochem. 2015, 50, 1885-1892. [CrossRef]

150. Ruoming, Y.; Qiang, W.; Xuerong, F.; Yuanyuan, Y.; Jiugang, Y.; Ping, W. A new model substrate for cutinase hydrolyzing polyethylene terephthalate. Fibers Polym. 2013, 14, 1128-1133. 
151. Silva, C.; Da, S.; Silva, N.; Matamá, T.; Araújo, R.; Martins, M.; Chen, S.; Chen, J.; Wu, J.; Casal, M.; Cavaco-Paulo, A. Engineered Thermobifida fusca cutinase with increased activity on polyester substrates. Biotechnol. J. 2011, 6, 1230-1239. [CrossRef]

152. Tkavc, T.; Vesel, A.; Acero, E.H.; Fras Zemljič, L. Comparison of oxygen plasma and cutinase effect on polyethylene terephthalate surface. J. Appl. Polym. Sci. 2013, 128, 3570-3575. [CrossRef]

153. Panseri, S.; Martino, P.A.; Cagnardi, P.; Celano, G.; Tedesco, D.; Castrica, M.; Balzaretti, C.; Chiesa, L.M. Feasibility of biodegradable based packaging used for red meat storage during shelf-life: A pilot study. Food Chem. 2018, 249, 22-29. [CrossRef] [PubMed]

154. Cayla, A.; Rault, F.; Giraud, S.; Salaün, F.; Fierro, V.; Celzard, A.; Cayla, A.; Rault, F.; Giraud, S.; Salaün, F.; et al. PLA with intumescent system containing lignin and ammonium polyphosphate for flame retardant textile. Polymers (Basel) 2016, 8, 331. [CrossRef]

155. Sabek, O.M.; Farina, M.; Fraga, D.W.; Afshar, S.; Ballerini, A.; Filgueira, C.S.; Thekkedath, U.R.; Grattoni, A.; Gaber, A.O. Three-dimensional printed polymeric system to encapsulate human mesenchymal stem cells differentiated into islet-like insulin-producing aggregates for diabetes treatment. J. Tissue Eng. 2016, 7, 1-13. [CrossRef] [PubMed]

156. Yao, Q.; Cosme, J.G.L.; Xu, T.; Miszuk, J.M.; Picciani, P.H.S.; Fong, H.; Sun, H. Three dimensional electrospun $\mathrm{PCL} / \mathrm{PLA}$ blend nanofibrous scaffolds with significantly improved stem cells osteogenic differentiation and cranial bone formation. Biomaterials 2017, 115, 115-127. [CrossRef] [PubMed]

157. Pellis, A.; Silvestrini, L.; Scaini, D.; Coburn, J.M.; Gardossi, L.; Kaplan, D.L.; Herrero Acero, E.; Guebitz, G.M. Enzyme-catalyzed functionalization of poly(L-lactic acid) for drug delivery applications. Process Biochem. 2017, 59, 77-83. [CrossRef]

158. Ortner, A.; Pellis, A.; Gamerith, C.; Orcal Yebra, A.; Scaini, D.; Kaluzna, I.; Mink, D.; de Wildeman, S.; Herrero Acero, E.; Guebitz, G.M. Superhydrophobic functionalization of cutinase activated poly(lactic acid) surfaces. Green Chem. 2017, 19, 816-822. [CrossRef]

159. Zaks, A.; Klibanov, A.M. Enzymatic catalysis in organic media at 100 degrees C. Science 1984, 224, $1249-1251$. [CrossRef] [PubMed]

160. De Barros, D.P.C.; Pinto, F.; Fonseca, L.P.; Cabral, J.M.S.; Lemos, F. Kinetic model for the esterification of ethyl caproate for reaction optimization. J. Mol. Catal. B Enzym. 2014, 101, 16-22. [CrossRef]

161. Dutta, K.; Hegde, K.; Dasu, V.V. Synthesis of methyl esters by transesterification catalyzed by cutinase from Pseudomonas cepacia NRRL B 2320 and kinetic analysis. Curr. Trends Biotechnol. Pharm. 2014, 8, 1-10.

162. Su, L.; Hong, R.; Guo, X.; Wu, J.; Xia, Y. Short-chain aliphatic ester synthesis using Thermobifida fusca cutinase. Food Chem. 2016, 206, 131-136. [CrossRef]

163. De Barros, D.P.; Pinto, F.; Pfluck, A.C.; Dias, A.S.; Fernandes, P.; Fonseca, L.P. Improvement of enzyme stability for alkyl esters synthesis in miniemulsion systems by using media engineering. J. Chem. Technol. Biotechnol. 2018, 93, 1338-1346. [CrossRef]

164. Nikolaivits, E.; Norra, G.-F.; Voutsas, E.; Topakas, E. Cutinase from Fusarium oxysporum catalyzes the acylation of tyrosol in an aqueous medium: Optimization and thermodynamic study of the reaction. J. Mol. Catal. B Enzym. 2016, 129, 29-36. [CrossRef]

165. Douka, A.; Vouyiouka, S.; Papaspyridi, L.-M.; Papaspyrides, C.D. A review on enzymatic polymerization to produce polycondensation polymers: The case of aliphatic polyesters, polyamides and polyesteramides. Prog. Polym. Sci. 2018, 79, 1-25. [CrossRef]

166. Feder, D.; Gross, R.A. Exploring chain length selectivity in HiC-catalyzed polycondensation reactions. Biomacromolecules 2010, 11, 690-697. [CrossRef] [PubMed]

167. Hunsen, M.; Azim, A.; Mang, H.; Wallner, S.R.; Ronkvist, A.; Wenchun Xie, A.; Gross, R.A. A cutinase with polyester synthesis activity. Macromolecules 2006, 40, 148-150. [CrossRef]

168. Hunsen, M.; Abul, A.; Xie, W.; Gross, R. Humicola insolens cutinase-catalyzed lactone ring-opening polymerizations: Kinetic and mechanistic studies. Biomacromolecules 2008, 9, 518-522. [CrossRef] [PubMed]

169. Pellis, A.; Ferrario, V.; Zartl, B.; Brandauer, M.; Gamerith, C.; Herrero Acero, E.; Ebert, C.; Gardossi, L.; Guebitz, G.M. Enlarging the tools for efficient enzymatic polycondensation: Structural and catalytic features of cutinase 1 from Thermobifida cellulosilytica. Catal. Sci. Technol. 2016, 6, 3430-3442. [CrossRef]

170. Stavila, E.; Arsyi, R.Z.; Petrovic, D.M.; Loos, K. Fusarium solani pisi cutinase-catalyzed synthesis of polyamides. Eur. Polym. J. 2013, 49, 834-842. [CrossRef] 
171. Stavila, E.; Alberda van Ekenstein, G.O.R.; Loos, K. Enzyme-catalyzed synthesis of aliphatic-aromatic oligoamides. Biomacromolecules 2013, 14, 1600-1606. [CrossRef] [PubMed]

(c)

(C) 2018 by the authors. Licensee MDPI, Basel, Switzerland. This article is an open access article distributed under the terms and conditions of the Creative Commons Attribution (CC BY) license (http://creativecommons.org/licenses/by/4.0/). 